\title{
The microRNA miR-31 inhibits CD8+ T cell function in chronic viral infection
}

\author{
Howell F Moffett ${ }^{1}$, Adam N R Cartwright ${ }^{1}$, Hye-Jung Kim ${ }^{1}$, Jernej Godec ${ }^{2}$, Jason Pyrdol ${ }^{1}$, \\ Tarmo Äijö ${ }^{3}$, Gustavo J Martinez ${ }^{4,6}$, Anjana Rao ${ }^{4}$, Jun $\mathrm{Lu}^{5}$, Todd R Golub ${ }^{5}$, Harvey Cantor ${ }^{1}$, \\ Arlene H Sharpe ${ }^{2}$, Carl D Novina ${ }^{1}$, and Kai W Wucherpfennig ${ }^{1,2}$
}

${ }^{1}$ Department of Cancer Immunology \& Virology, Dana-Farber Cancer Institute, Boston, Massachusetts, USA ${ }^{2}$ Department of Microbiology and Immunobiology, Harvard Medical School, Boston, Massachusetts, USA ${ }^{3}$ Department of Information and Computer Science, Aalto University School of Science, Aalto, Finland ${ }^{4}$ La Jolla Institute for Allergy and Immunology, La Jolla, California, USA ${ }^{5}$ Broad Institute of MIT and Harvard, Cambridge, Massachusetts, USA

\section{Abstract}

During infection, antigen-specific $\mathrm{T}$ cells undergo tightly regulated developmental transitions controlled by transcriptional and post-transcriptional regulation of gene expression. We found that the microRNA miR-31 was strongly induced by activation of the T cell antigen receptor (TCR) in a pathway involving calcium and activation of the transcription factor NFAT. During chronic infection with lymphocytic choriomeningitis virus (LCMV) clone 13, miR-31-deficent mice recovered from clinical disease, while wild-type mice continued to show signs of disease. This disease phenotype was explained by the presence of larger numbers of cytokine-secreting LCMVspecific $\mathrm{CD}^{+} \mathrm{T}$ cells in miR-31-deficent mice than in wild-type mice. Mechanistically, miR-31 increased the sensitivity of $\mathrm{T}$ cells to type I interferons, which interfered with effector $\mathrm{T}$ cell function and increased the expression of several proteins related to $\mathrm{T}$ cell dysfunction during chronic infection. These studies identify miR-31 as an important regulator of $\mathrm{T}$ cell exhaustion in chronic infection.

The control of pathogens and cancers requires proper functioning of the adaptive immune system. $\mathrm{CD} 8^{+} \mathrm{T}$ cells are a crucial component of such immune responses; they are able to undergo massive population expansion to produce a large pool of effector cells that eliminate

reprints and permissions information is available online at http://www.nature.com/reprints/index.html

Correspondence should be addressed to: K.W.W. (kai_wucherpfennig@dfci.harvard.edu).

6 Present address: Department of Microbiology and Immunology, Chicago Medical School, Rosalind Franklin University of Medicine and Science, North Chicago, Illinois, USA.

AUTHOR CONTRIBUTIONS

H.F.M. and K.W.W. designed the study and discussed and analyzed data; H.F.M., A.N.R.C. and K.W.W. wrote the paper; H.F.M. and A.N.R.C. performed experiments and analyzed data; H.-J.K. and J.G. helped with infection experiments; J.P. performed immunoblot analysis; T.A., G.J.M. and A.R. provided NFAT chromatin-immunoprecipitation data; J.L. and T.R.G. performed miRNA profiling; H.C., A.H.S. and C.D.N. provided advice on experimental design and data interpretation; and K.W.W. supervised the study. 
virus-infected or transformed cells. $\mathrm{CD}^{+} \mathrm{T}$ cells continuously integrate many distinct signals through the T cell antigen receptor (TCR) as well as through co-stimulatory, coinhibitory, cytokine and chemokine receptors. These environmental signals either promote pathogen clearance and long-term memory or can result in immune-system dysfunction and $\mathrm{T}$ cell exhaustion. These disparate outcomes are dependent on changes in multiple networks of genes encoding proteins that affect the survival, proliferation and effector function of cells ${ }^{1}$.

MicroRNAs (miRNAs) are a class of small non-coding RNAs that regulate gene expression by translational repression and mRNA destabilization. Deletion of the key miRNAbiosynthetic enzyme Dicer during thymic $\mathrm{T}$ cell development markedly diminishes the abundance of $\mathrm{CD} 8^{+} \mathrm{T}$ cells in the periphery ${ }^{2,3}$, and deletion of Dicer in mature $\mathrm{CD} 8^{+} \mathrm{T}$ cells impairs the effector response of $\mathrm{CD} 8^{+} \mathrm{T}$ cells in vivo ${ }^{4}$. Individual miRNAs have important roles in the activation of $\mathrm{CD}^{+} \mathrm{T}$ cells. The miR-17-92 cluster regulates the proliferation of $\mathrm{CD}^{+} \mathrm{T}$ cells after activation and shapes effector and memory differentiation ${ }^{5}$. Other miRNAs shape signaling from TCRs and cytokine receptors. miR-146 is part of a negative feedback loop induced by the TCR and pro-inflammatory cytokines that inhibits activation of the transcription factor NF- $\mathrm{B}^{6,7}$. In contrast, miR-155 enhances pro-inflammatory cytokine signaling by repressing the signaling inhibitor SOCS1 and promotes the population expansion of anti-viral $\mathrm{CD} 8^{+} \mathrm{T}$ cells by blocking the anti-proliferative effect of type I interferons ${ }^{8,9}$. Alterations in miRNA expression can also act downstream of cytokine signaling in $\mathrm{CD}^{+} \mathrm{T}$ cells. For example, signaling via interleukin 2 (IL-2) and inflammatory cytokines drives the differentiation of $\mathrm{CD} 8^{+} \mathrm{T}$ cells by repressing the expression of miR-150 and miR-139 (ref. 10). However, the function of most miRNAs expressed by $\mathrm{CD} 8^{+} \mathrm{T}$ cells remains unknown.

Here we report that the expression of miR-31 was strongly induced following the activation of $\mathrm{T}$ cells via TCR signaling through pathways dependent on calcium and the transcription factor NFAT. The expression of miR-31 promoted $\mathrm{T}$ cell dysfunction by enhancing the expression of multiple inhibitory molecules, particularly during exposure to type I interferons. During chronic viral infection, miR-31 promoted the dysfunction of $\mathrm{CD} 8^{+} \mathrm{T}$ cells and impaired viral control in a $\mathrm{T}$ cell-intrinsic manner. These results identify a role for miR-31 in promoting the exhaustion of $\mathrm{CD} 8^{+} \mathrm{T}$ cells.

\section{RESULTS}

\section{TCR triggering induces sustained expression of miR-31}

To globally define miRNA expression during $\mathrm{T}$ cell activation and differentiation, we used a bead-based assay to profile miRNAs in $\mathrm{CD} 8^{+} \mathrm{T}$ cells before and after activation via a complex of the TCR and its invariant chain CD3 with an antibody to CD3 (anti-CD3) and an antibody to the co-stimulatory receptor $\mathrm{CD} 28$ (anti-CD28). These profiling data revealed dynamic regulation of miRNA expression during T cell activation (Fig. 1a, Supplementary Fig. 1 and Supplementary Table 1). Several of the miRNAs upregulated following activation, including miR-146a, miR-155 and miR-17-miR-18a from the miR-17-92 cluster, have established functions in $\mathrm{CD}^{+} \mathrm{T}$ cells ${ }^{5-9}$, while many of the other upregulated miRNAs do not have annotated functions in T cells. Of particular interest, miR-31 was not expressed in 
total thymocytes or naive $\mathrm{CD} 8^{+} \mathrm{T}$ cells, but its expression was substantially upregulated following the activation of $\mathrm{CD} 8^{+} \mathrm{T}$ cells (Fig. 1a). Consistent with the profiling data, quantification of miR-31 expression by quantitative PCR (qPCR) indicated upregulation of $>100$-fold in the expression of miR-31 in CD8 ${ }^{+} \mathrm{T}$ cells following stimulation with anti-CD3 plus anti-CD28 relative to its expression in naive $\mathrm{CD} 8^{+} \mathrm{T}$ cells (Fig. 1b). We also observed upregulation of $\sim 10$-fold in the expression of miR-31 in $\mathrm{CD}^{+} \mathrm{T}$ cells following activation with anti-CD3 plus anti-CD28 and in natural killer (NK) cells following stimulation with the phorbol ester PMA and ionomycin, relative to its expression in the corresponding unstimulated cell populations (Fig. 1b). However, miR-31 expression was not induced in $\mathrm{CD} 19^{+} \mathrm{B}$ cells following stimulation with an antibody specific for immunoglobulin $\mathrm{M}$ and a CpG oligo-nucleotide (Fig. 1b). Kinetic studies demonstrated a rapid increase in miR-31 expression in $\mathrm{CD}^{+} \mathrm{T}$ cells stimulated with anti-CD3 plus anti-CD28, with induction of $\sim 100$-fold at $8 \mathrm{~h}$ after activation relative to the expression before activation (Fig. 1c). Stimulation of naive OT-I CD8 ${ }^{+} \mathrm{T}$ cells (which have transgenic expression of an ovalbumin (OVA)-specific TCR) with dendritic cells (DCs) and OVA peptide also rapidly induced an increase of $>100$-fold in the expression of miR-31 relative to its expression in unstimulated $\mathrm{CD} 8^{+} \mathrm{T}$ cells (Fig. 1d). These results indicated that miR-31 expression was induced in activated $\mathrm{CD}^{+}$and $\mathrm{CD} 8^{+} \mathrm{T}$ cells, as well as in NK cells, with the highest expression in activated $\mathrm{CD} 8^{+} \mathrm{T}$ cells.

To investigate whether miR-31 expression was maintained in activated $\mathrm{T}$ cells, we quantified its expression 1 and 2 weeks following stimulation. Naive $\mathrm{CD} 8^{+} \mathrm{T}$ cells isolated from OT-I mice were stimulated for $72 \mathrm{~h}$ with OVA peptide, followed by culture with IL-2 or IL-15. The expression of miR-31 remained high for 2 weeks in CD8 ${ }^{+} \mathrm{T}$ cells cultured with IL-2 (Fig. 1e). In contrast, its expression progressively decreased in $\mathrm{CD}^{+} \mathrm{T}$ cells cultured with IL-15, although it remained higher at $7 \mathrm{~d}$ and $14 \mathrm{~d}$ in those cells than in naive $\mathrm{CD} 8^{+} \mathrm{T}$ cells (Fig. 1e). Treatment of naive CD8 ${ }^{+} \mathrm{T}$ cells with the cytokines IL-2, IL-7 or IL-15 in the absence of TCR stimulation did not induce the expression of miR-31 (Supplementary Fig. $2 \mathrm{a}-\mathrm{c}$ ), which indicated that those cytokines were not sufficient to induce mir-31 expression.

We also investigated the expression of miR-31 ex vivo. Populations of CD4 ${ }^{+}$or CD8 ${ }^{+}$ effector and effector-memory $\mathrm{T}$ cells, as well as central memory $\mathrm{T}$ cells, had higher expression of miR-31 than that of their naive counterparts; the highest expression was observed in activated CD25+ $\mathrm{CD}^{+} \mathrm{T}$ cells (Fig. 1f). $\mathrm{T}$ cell activation induces degradation of Argonaute proteins (which are essential for the assembly and function of the miRNAcontaining RNA-induced silencing complex) and remodeling of the miRNA repertoire ${ }^{11}$. We confirmed induction of miR-31 expression in activated T cells through the use of the small nucleolar RNA sno234 as a standard (Supplementary Fig. 2d-f). These results indicated that increased miR-31 expression was a feature of effector $\mathrm{CD} 4^{+}$and $\mathrm{CD} 8^{+} \mathrm{T}$ cell subsets as well as memory $\mathrm{CD}^{+}$and $\mathrm{CD} 8^{+} \mathrm{T}$ cell subsets.

\section{The induction of miR-31 is dependent on calcium signaling}

The rapid induction of miR-31 after $\mathrm{T}$ cell activation places the gene encoding miR-31 (Mir31) among the early-response genes, many of which are transcriptionally activated through the calcium-NFAT pathway. Treatment of $\mathrm{CD} 8^{+} \mathrm{T}$ cells with ionomycin, a calcium 
ionophore, was sufficient to induce miR-31 expression, albeit at a lower level than that induced by stimulation with anti-CD3 plus anti-CD28, while inhibition of calcium signaling with cyclosporine A blocked the induction of miR-31 following treatment with ionomycin or stimulation with anti-CD3 plus anti-CD28 (Fig. 2a). Expression (via a lentiviral vector) of constitutively active NFAT1 containing serine-to-alanine substitutions of key residues within the regulatory domain ${ }^{12}$ in $\mathrm{CD}^{+} \mathrm{T}$ cells induced expression of miR-31 to levels similar to those achieved with ionomycin treatment (Fig. 2b). Genome-wide analysis of the binding of NFAT1 by chromatin immunoprecipitation in $\mathrm{CD} 8^{+} \mathrm{T}$ cells stimulated with PMA and ionomycin revealed three binding peaks upstream of the miR-31 hairpin on mouse chromosome 4 (Fig. 2c), one of which was located near a $\mathrm{CpG}$ island homologous to the promoter of the human gene encoding miR-31 $(M I R 31 H G)^{13,14}$. The binding of NFAT1 to these genomic elements was not observed in resting $\mathrm{CD} 8^{+} \mathrm{T}$ cells or in $\mathrm{CD} 8^{+} \mathrm{T}$ cells stimulated with PMA and ionomycin and also treated with cyclosporin A (Fig. 2c). These data indicated that calcium signaling and subsequent NFAT transcriptional activity were linked to the induction of miR-31 via TCR activation in $\mathrm{CD}^{+} \mathrm{T}$ cells.

\section{Identification of miR-31 target genes in $\mathrm{CD}^{+} \mathrm{T}$ cells}

miRNAs repress many target mRNAs, but accurate prediction of their targets is challenging due to the partial complementarity of mammalian miRNA-mRNA pairs and limited understanding of the factors that regulate the binding of miRNAs ${ }^{15}$. Because regulation by a miRNA reduces the abundance of the majority of target mRNAs, we used expression profiling ${ }^{16,17}$ of OT-I CD8 ${ }^{+} \mathrm{T}$ cells transduced with a lentiviral vector expressing miR-31 and enhanced green fluorescent protein (eGFP) (lenti-miR31), or a control vector expressing eGFP alone (lenti-eGFP) to identify targets of miR-31. Transduction of cells with lentimiR31 resulted in significant changes in mRNA expression relative to that of cells transduced with lenti-eGFP (Fig. 3a). The interaction between miRNAs and repressed target mRNAs occurs mainly in the $3^{\prime}$ untranslated region (UTR) of the target mRNAs ${ }^{18}$. The mRNAs downregulated in $\mathrm{CD}^{+} \mathrm{T}$ cells transduced with lenti-miR31 relative to their expression in $\mathrm{CD}^{+} \mathrm{T}$ cells transduced with lenti-eGFP showed considerable enrichment for predicted miR-31-binding sites (relative to the abundance of mRNAs that were expressed but not regulated differentially): $57 \%$ of mRNAs with reduced abundance (68 of 199) contained a predicted binding site in the $3^{\prime}$ UTR (Fig. 3b). We further validated 15 targets of miR-31 by cloning their $3^{\prime}$ UTRs downstream of a luciferase reporter vector; 13 of these $3^{\prime}$ UTRs resulted in lower luciferase activity in the presence of exogenous miR-31 than that of cells transduced with a luciferase vector without an inserted $3^{\prime}$ UTR (Fig. 3c). Several of these (Ppp6c, Lats2, Oxsr1, Elav11 (ref. 19) and Stk4O) ${ }^{20-23}$ have been reported as targets of miR-31, while eight mRNAs (Psd4, Sh2d1a, Ilf3, Coro7, Rab1b, Stra13, Cdkn1a and Ifi30) represented newly identified targets of miR-31 (Fig. 3c). These results identified previously unknown targets of miR-31 in activated mouse $\mathrm{CD}^{+} \mathrm{T}$ cells.

\section{miR-31 promotes CD8+ T cell dysfunction}

To investigate the function of miR-31 in vivo, we deleted Mir31 in the germline of C57BL/6 mice by crossing mice with loxP-flanked Mir31 alleles (Mir3 $1^{\mathrm{fl} / \mathrm{fl} 1}$ ) to mice expressing Cre recombinase under the control of the promoter of the gene encoding the glyco-protein Zp3 ( $Z p 3$-Cre) to generate Mir3 $1^{\mathrm{fl} / \mathrm{fl}} Z p 3$-Cre mice (called 'Mir31-l-, mice here; Supplementary 
Fig. 3a). We also deleted Mir31 conditionally in T cells by crossing Mir31 $1^{\mathrm{fl} / \mathrm{fl}}$ mice with mice in which Cre is expressed under the control of the T cell-specific $C d 4$ promoter

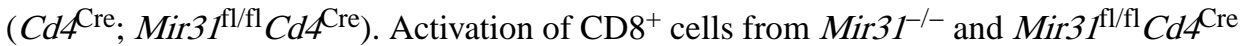
mice with anti-CD3 plus anti-CD28 demonstrated complete loss of miR-31 expression relative to that of activated wild-type or Mir3 $1^{\mathrm{fl} / \mathrm{fl}} \mathrm{CD}^{+} \mathrm{T}$ cells (Supplementary Fig. 3b,c). Mir31 $1^{-/}$mice were born at the expected Mendelian ratios, displayed no anatomical alterations and had cellularity and mature $\mathrm{T}$ cell subset composition in the thymus, spleen and peripheral lymph nodes similar to that of wild-type mice (data not shown).

Ingenuity-pathway analysis of all mRNAs expressed differentially in CD8 ${ }^{+} \mathrm{T}$ cells transduced with lenti-miR31 relative to their expression in $\mathrm{CD} 8^{+} \mathrm{T}$ cells transduced with lenti-eGFP revealed correlations with pathways linked to type I interferons, including alterations in the expression of Ifna 2 mRNA (which encodes the interferon IFN-a2), and Irf3 mRNA and Irf7 mRNA (which encode the transcription factors IRF3 and IRF7, respectively) (Supplementary Table 2 ). We therefore analyzed $\mathrm{CD}^{+} \mathrm{T}$ cells from wild-type and Mir31-/- mice by RNA-based next-generation sequencing (RNA-seq) on day 7 following in vitro stimulation with anti-CD3 plus anti-CD28 and culture in IL-2, with or without stimulation with IFN- $\beta$ for $18 \mathrm{~h}$ before analysis. Mir31 ${ }^{-1-} \mathrm{CD} 8^{+} \mathrm{T}$ cells had significantly higher expression of mRNAs encoding $\mathrm{T}$ cell effector molecules, including perforin (Prf1) and several granzymes (Gzmd, Gzmc, Gzme, Gzmg and Gzmb), as well as osteopontin ( $S p p 1)$, than that of wild-type cells, with these changes in gene expression being more prominent following stimulation with IFN- $\beta$ (Fig. 4a,b). In addition, several genes encoding products known to promote $\mathrm{T}$ cell dysfunction, including intracellular metallothioneins (Mt1 and Mt2), which contribute to T cell dysfunction in mouse tumors, as well as the transcription factor c-Maf (Maf) and the receptor for prostaglandin $\mathrm{E}_{2}$ (Ptger2), which contribute to $\mathrm{CD}^{+} \mathrm{T}$ cell dysfunction in a model of chronic infection with lymphocytic choriomeningitis virus (LCMV) clone 13 (refs. 1,24,25), had higher expression in wild-type $\mathrm{CD}^{+} \mathrm{T}$ cells than in $\mathrm{Mir}^{-1} \mathrm{1}^{-1-} \mathrm{CD}^{+} \mathrm{T}$ cells (Fig. 4a,b). Consistent with those findings, gene-set-enrichment analysis identified 'LCMV Armstrong versus clone 13' as well as 'Effector versus exhausted $\mathrm{CD}^{+}{ }^{+} \mathrm{T}$ cell' as major gene-expression signatures at $0 \mathrm{~h}$ and $18 \mathrm{~h}$, respectively, after stimulation with IFN- $\beta$ (Fig. 4c). Validation of those RNA-seq data by qPCR indicated that Maf mRNA and Ptger 2 mRNA had lower expression in Mir31 $^{-1-} \mathrm{CD}^{+} \mathrm{T}$ cells than in wild-type $\mathrm{CD}^{+} \mathrm{T}$ cells following treatment with IFN- $\beta$ (Fig. 4d). The expression of mRNA encoding perforin (Prf1 mRNA) was higher in Mir31-/$\mathrm{CD}^{+} \mathrm{T}$ cells than in wild-type $\mathrm{CD}^{+} \mathrm{T}$ cells only following stimulation with IFN- $\beta$ (Fig. $4 d)$. Stimulation with IFN- $\beta$ also increased the differences in the expression of granzymeencoding mRNAs as well osteopontin-encoding mRNA (Spp1) in Mir31-/- CD8 ${ }^{+}$T cells relative to their expression in wild-type $\mathrm{CD}^{+} \mathrm{T}$ cells (Fig. 4d). Flow cytometry showed that treatment with IFN- $\beta$ also resulted in a greater abundance of per-forin and granzyme $\mathrm{C}$ in Mir31-l- $\mathrm{CD}^{+} \mathrm{T}$ cells than in wild-type $\mathrm{CD}^{+} \mathrm{T}$ cells (Fig. $\left.4 \mathrm{e}\right)$. Immunoblot analysis indicated only small differences between Mir31 $^{-1-} \mathrm{CD}^{+} \mathrm{T}$ cells and wild-type $\mathrm{CD} 8^{+} \mathrm{T}$ cells in phosphorylation of the transcription factor STAT1 following treatment with IFN- $\beta$ (Supplementary Fig. 4a-d). Also, there were only small differences between those cells in their expression of the transcription factors STAT1, STAT2 and IRF9 and of SOCS1 (Supplementary Fig. 4e). Type 1 interferons are important for the initial activation of CD8 ${ }^{+}$ 
$\mathrm{T}$ cells ${ }^{26}$. However, miR-31 is expressed only following TCR activation and might therefore regulate the effects of secondary or chronic exposure to type I interferons. In models of chronic viral infection, continued exposure to type I interferons impairs $\mathrm{T}$ cell responses and drives disease progression ${ }^{27-29}$.

To address which targets of miR-31 might regulate sensitivity to type I interferons, we transduced the 7678 mouse $\mathrm{T}$ cell hybridoma with lentiviral vectors containing short hairpin RNA (shRNA) targeting each of four miR-31-regulated genes (Lats2, Stk4O, Ppp6c and Sh2d1a) or a control lentiviral vector and assessed expression of the activation marker CD69, which is induced by type I interferons. Transduction of cells with lenti-miR31 or with shRNA for silencing the miR-31 target $P p p 6 c$ enhanced their sensitivity to IFN- $\beta$ relative to that of cells transduced with the respective control lentiviral vector (Supplementary Fig. 5a). Ppp6c is a phosphatase that regulates cytokine signaling through the kinase Map3k7 and has been linked to inhibition of type I interferon signaling in a high-throughput screen ${ }^{30-32}$. In contrast, transduction of the $7678 \mathrm{~T}$ cell hybridoma with shRNA targeting Lats2, Stk4O or Sh2d1a had no effect on responsiveness to IFN- $\beta$ (Supplementary Fig. 5a). To confirm those findings in primary T cells, we transduced Mir31 $1^{-1-}$ OT-I T cells with lenti-miR31, shRNA targeting $P p p 6 c$ or the respective control lentiviral vector. Transduction with lenti-miR31 or shRNA targeting Ppp6c increased the sensitivity of $\mathrm{CD} 8^{+} \mathrm{T}$ cells to IFN- $\beta$ relative to that of $\mathrm{CD} 8^{+} \mathrm{T}$ cells transduced with the respective control lentiviral vector (Supplementary Fig. 5b). We also measured Ppp6c by immunoblot analysis of OT-I CD8 ${ }^{+} \mathrm{T}$ cells activated with OVA peptide and observed approximately four-fold lower expression of Ppp6c in wild-type $\mathrm{CD}^{+} \mathrm{T}$ cells than in Mir31-l- T cells (Supplementary Fig. $5 \mathrm{c}, \mathrm{d}$ ). These results suggested a role for miR-31 in 'tuning' the sensitivity of $\mathrm{CD} 8^{+} \mathrm{T}$ cells to type I interferon signaling.

\section{miR-31 inhibits $T$ cell responses to chronic infection}

In adult mice, LCMV Armstrong strain causes an acute infection that is cleared by day 8 after infection, while LCMV clone 13 causes a chronic infection that persists $>90 \mathrm{~d}$ after infection. Both expression of the inhibitory receptor PD-1 and signaling via type I interferons are critical for the chronic infection of mice with LCMV clone 13 (refs. 33-35), while blockade of chronic signaling via type I interferons results in control of infection with LCMV clone 13 (refs. 34,35). We next investigated if miR-31 has a role in controlling the chronicity of infection with LCMV clone 13 . The initial disease course was similar in wildtype mice and Mir31-I- mice infected with LCMV clone 13, with all mice displaying disease symptoms at days 9-11 after infection (Fig. 5a,b). Wild-type mice exhibited signs of chronic disease and wasting, while Mir31 $1^{-1-}$ mice showed no signs of disease and had recovered $\sim 95 \%$ of their initial body weight by day 20 after infection (Fig. 5a,b). We next sought to determine whether disease resolution was associated with control of the virus. During the acute phase of the infection (day 9 after infection), wild-type mice and Mir31-/mice had similar titers of circulating virus (Fig. 5c). However, by day 20 after infection, viral titers were significantly $(>1.5-\log )$ lower in the serum of Mir31 $1^{-1-}$ mice than in that of wildtype mice (Fig. 5c). We also detected lower levels of viral RNA in tissue samples from Mir $31^{-1-}$ mice than in those from wild-type mice at day 30 after infection (Supplementary Fig. 6a). These results suggested that miR-31 impaired the control of infection with LCMV clone 13. 
We next investigated whether early disease resolution and improved viral control were associated with enhanced anti-viral $\mathrm{CD} 8^{+} \mathrm{T}$ cell responses. The frequency of $\mathrm{CD} 8^{+} \mathrm{T}$ cells positive for a tetramer (Tet) of LCMV glycoprotein (amino acids 33-41) in blood was similar in wild-type mice and Mir $31^{-1-}$ mice on day 8 after infection with LCMV clone 13 (Fig. 6a). However, on day 20 after infection, Mir31-1- mice had a higher frequency of $\mathrm{Tet}^{+}$ $\mathrm{CD} 8^{+} \mathrm{T}$ cells in blood than that of wild-type mice (Fig. 6a,b). At day 20 after infection, more $\mathrm{Tet}^{+} \mathrm{CD} 8^{+} \mathrm{T}$ cells in the blood of $\mathrm{Mir} 31^{-/-}$mice than in that of wild-type mice expressed the effector $\mathrm{T}$ cell marker KLRG1, and fewer $\mathrm{Tet}^{+} \mathrm{CD} 8^{+}$cells in the blood of Mir $31^{-1-}$ mice than in that of wild-type mice expressed PD-1 (Fig. 6a-c). At day 30 after infection, there was a greater frequency of $\mathrm{CD}^{+} \mathrm{T}$ cells in the spleen of $\mathrm{Mir} 31^{-1-}$ mice than in that of wild-type mice, an increase driven by the population expansion of $\mathrm{CD} 44^{+} \mathrm{CD}^{2} 2 \mathrm{~L}^{-}$ $\mathrm{CD} 8^{+}$effector and effector-memory $\mathrm{T}$ cells (Fig. 6d). Tetramer labeling indicated population expansion of $\mathrm{Tet}^{+} \mathrm{KLRG}^{+}{ }^{+} \mathrm{CD} 8^{+} \mathrm{T}$ cells and $\mathrm{Tet}^{+} \mathrm{KLRG1}^{-} \mathrm{CD} 127^{-} \mathrm{CD} 8^{+} \mathrm{T}$ cells in Mir $31^{-1-}$ mice relative to the size of those populations in wild-type mice at $30 \mathrm{~d}$ after infection, while the frequency of $\mathrm{Tet}^{+} \mathrm{CD} 127^{+} \mathrm{CD} 8^{+} \mathrm{T}$ cells in Mir $31^{-1-}$ mice was similar to that of wild-type mice (Fig. 6e).

We did not observe a difference between wild-type mice and $\mathrm{Mir} 31^{-1-}$ mice in their $\mathrm{CD} 44^{+} \mathrm{CD} 62 \mathrm{~L}^{-} \mathrm{CD} 4{ }^{+}$effector and effector-memory T cells (Fig. 6f). Also, we did not detect differences between wild-type mice and Mir31-1- mice in their titers of LCMV-specific antibodies (Fig. $6 \mathrm{~g}$ ). $\mathrm{CD}^{+} \mathrm{Foxp}^{+}$regulatory $\mathrm{T}$ cells undergo population expansion during infection with LCMV clone 13 and inhibit the response of $\mathrm{CD}^{+} \mathrm{T}$ cells to $\mathrm{LCMV}^{36,37}$. miR-31 is known to inhibit the differentiation of $\mathrm{CD}^{+}$regulatory $\mathrm{T}$ cells in humans through direct regulation of expression of the transcription factor Foxp3 and inhibits the differentiation of induced regulatory $\mathrm{T}$ cells in mice through repression of the G-proteincoupled receptor Gprc5 $\mathrm{a}^{38,39}$. We therefore investigated the role of miR-31 in regulating the expression of Foxp3 in mice. We found that a luciferase reporter linked to the mouse Foxp3 $3^{\prime}$ UTR was not repressed by miR-31 (Supplementary Fig. 6b). We also did not observe differences in the frequency of Foxp $3^{+} \mathrm{CD}^{+} \mathrm{T}$ cells isolated from the spleen of Mir $31^{-1-}$ mice versus those isolated from that of wild-type mice at baseline or at day 30 following infection with LCMV clone 13 (Fig. 6h and Supplementary Fig. 6c). In mice challenged with influenza virus (strain X31-gp33), weight loss, viral burden in the lungs and the frequency of influenza-virus-specific $\mathrm{CD} 8^{+} \mathrm{T}$ cells were similar in $\mathrm{Mir} 3 \mathrm{I}^{+/-}$mice and Mir31 $1^{-1-}$ mice on day 8 following infection (Supplementary Fig. 7); this confirmed that miR-31 inhibited $\mathrm{CD} 8^{+} \mathrm{T}$ cell responses during chronic infection but not during acute infection.

\section{T cell-intrinsic effect of miR-31 in chronic LCMV infection}

To isolate T cell-intrinsic effects of miR-31, we infected Mir $31^{\mathrm{fl} / \mathrm{fl}} \mathrm{Cd} 4^{\mathrm{Cre}}$ mice with LCMV clone 13. The disease course in Mir $31^{\mathrm{fl} / \mathrm{fl}} \mathrm{Cd} 4^{\mathrm{Cre}}$ mice was similar to that of $\mathrm{Mir} 31^{-1-}$ mice following infection with LCMV clone 13, with rapid resolution of disease, in contrast to the chronic disease observed in wild-type mice (Fig. 7a). Mir $3 I^{\mathrm{fl} / \mathrm{fl}} \mathrm{Cd} 4^{\mathrm{Cre}}$ mice had a greater frequency of circulating $\mathrm{Tet}^{+} \mathrm{CD} 8^{+} \mathrm{T}$ cells at day 20 after infection, and lower expression of PD-1, compared with that of wild-type mice (Fig. 7b,c). We also observed a greater abundance of total $\mathrm{Tet}^{+} \mathrm{KLRG}^{+}{ }^{+} \mathrm{CD} 8^{+} \mathrm{T}$ cells and $\mathrm{Tet}^{+} \mathrm{KLRG}^{-} \mathrm{CD} 127^{-} \mathrm{CD} 8^{+} \mathrm{T}$ cells in 
the spleen of $\mathrm{Mir} 3 \mathrm{f}^{\mathrm{fl} / \mathrm{fl}} \mathrm{Cd} 4^{\mathrm{Cre}}$ mice on 28 after infection relative to the abundance of such cells in the spleen of wild-type mice (Fig. 7d). These results demonstrated that miR-31 promoted $\mathrm{CD} 8^{+} \mathrm{T}$ cell dysfunction and the chronicity of infection with LCMV clone 13 in a T cell-intrinsic manner.

Because $\mathrm{CD} 8^{+} \mathrm{T}$ cells progressively lose the ability to secrete the cytokines IL- 2 and TNF and, finally, IFN- $\gamma^{40}$ during chronic viral infection, we assessed the functionality of antigen-

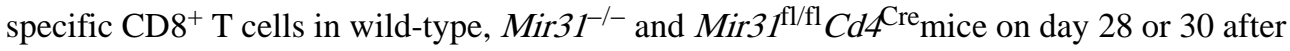
infection with LCMV clone 13. Splenocytes from infected mice were pulsed ex vivo with the peptides GP33 and GP276 (from LCMV glycoprotein) and NP396 (from LCMV nucleoprotein), followed by intracellular cytokine staining for IFN- $\gamma$, TNF and IL-2 in $\mathrm{CD} 8^{+} \mathrm{T}$ cells. We found significantly more IFN- $\gamma^{+} \mathrm{CD} 8^{+} \mathrm{T}$ cells responsive to stimulation with the epitopes GP33 and GP276 in the spleen of Mir31--- mice and Mir3 $1^{\mathrm{fl} / \mathrm{fl} \mathrm{C}} \mathrm{Cd} \mathrm{Cre}^{\mathrm{re}}$ mice than in that of wild-type mice (Fig. 8a,c). We also observed more polyfunctional IFN-

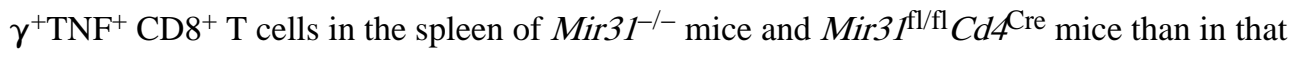
of wild-type mice (Fig. 8b,d). It has been suggested that miR-31 promotes the secretion of IL-2 by T cells ${ }^{40,41}$. However, we did not observe differences in the secretion of IL-2 from wild-type, Mir3 $1^{-/-}$or Mir3 $31^{\mathrm{fl} / \mathrm{fl}} \mathrm{Cd} 4^{\mathrm{Cre}} \mathrm{CD} 8^{+} \mathrm{T}$ cells in response to stimulation with LCMV peptide (data not shown), and stimulation with PMA plus ionomycin induced a similar frequency of $\mathrm{IL}-2^{+} \mathrm{CD} 4^{+} \mathrm{T}$ cells and $\mathrm{IL}-2^{+} \mathrm{CD} 8^{+} \mathrm{T}$ cells in all mouse strains (Supplementary Fig. 8a). Comparison of cytokine secretion in response to GP33 peptide versus total $\mathrm{Tet}^{+} \mathrm{T}$ cells indicated that $\mathrm{Mir} 3 \mathrm{I}^{-1-}$ mice had a more functional effector pool than that of wild-type mice: Mir31-l- mice had 1.9-fold more IFN- $\gamma^{+} \mathrm{CD} 8^{+} \mathrm{T}$ cells than wild-type mice had, even after correction for a larger population of $\mathrm{Tet}^{+} \mathrm{CD} 8^{+} \mathrm{T}$ cells (Supplementary Fig. 8b). These results indicated that miR-31 impaired the function of CD8 ${ }^{+}$ $\mathrm{T}$ cells in a T cell-intrinsic manner during chronic infection with LCMV clone 13.

\section{DISCUSSION}

Here we have shown substantial induction of miR-31 following $\mathrm{T}$ cell activation via a process involving calcium signaling and binding of NFAT to the locus encoding miR-31. During chronic infection with LCMV clone 13, Mir31 $1^{-1-}$ mice had a larger and more functional antigen-specific $\mathrm{CD} 8^{+} \mathrm{T}$ cell response than that of wild-type mice, which was associated with recovery from infection and control of viral replication. Gene-expression studies revealed that the absence of miR-31 diminished the expression of genes encoding products associated with $\mathrm{T}$ cell dysfunction, including c-Maf, the prostaglandin $\mathrm{E}_{2}$ receptor and metallothioneins, and also enhanced $\mathrm{T}$ cell effector programs. Those differences appeared in particular after treatment with type I interferons. Our data demonstrated that miR-31 promoted $\mathrm{CD} 8^{+} \mathrm{T}$ cell exhaustion during the chronic stage of infection.

Early during viral infection, type I interferons promote the priming of anti-viral CD8 ${ }^{+} \mathrm{T}$ cells. Treatment of mice with exogenous type I interferons at very early time points following infection with LCMV enhances anti-viral CD8 $8^{+} \mathrm{T}$ cell responses and improves viral control ${ }^{42}$. However, sustained production of type I interferons during infection with LCMV clone 13 inhibits $\mathrm{T}$ cell-mediated clearance of the virus by suppressing proliferation and increasing the expression of PD-1 by T cells ${ }^{43-45}$. Antibody blockade of the receptor for 
IFN- $\alpha$ and IFN- $\beta$ during chronic infection with LCMV has been shown to promote viral clearance $^{34,35}$. Mechanistically, blockade of that receptor is associated with reduced expression of the PD-1 ligand PD-L1. We showed that shRNA-mediated knockdown of the miR-31 target Ppp6c increased the sensitivity of $\mathrm{CD} 8^{+} \mathrm{T}$ cells to type I interferons in vitro and thus was a phenocopy of the effects of miR-31 expression in these cells. The phosphatase Ppp6c has been identified as a negative regulator of interferon signaling in mouse embryonic fibroblasts ${ }^{29}$. Given that miRNAs typically target many different mRNAs, it is possible that miR-31 targets other mRNAs (in addition to Ppp6c) that contribute to the regulation of interferon signaling in T cells. Also, the contribution of Ppp6c to the in vivo phenotype in Mir31-- mice remains to be determined.

We did not observe a diminished $\mathrm{CD} 8^{+} \mathrm{T}$ cell response to acute infection with influenza virus or LCMV in miR-31-deficient mice. While the induction of mir-31 occurred rapidly after $\mathrm{T}$ cell activation, the in vivo effects of miR-31 deficiency were evident only after a substantial delay. That pattern is consistent with what has been observed for other activationinduced miRNAs, such as miR-155 (ref. 8). In part, this delay is probably due to the kinetics of miRNA expression and the relative stability of the proteins encoded by the targets of miRNA. Argonaute proteins, which are the effectors of the miRNA-induced silencing complex, are post-transcriptionally downregulated following $\mathrm{T}$ cell activation through ubiquitination and proteasome-mediated degradation. This mechanism might substantially delay the miRNA-mediated regulation of mRNA targets ${ }^{11}$.

The expression of miR-31 increases the abundance of proteins that contribute to $\mathrm{T}$ cell dysfunction. The abundance of mRNA encoding prostaglandin $\mathrm{E}_{2}$ receptor (Ptger2) increased in $\mathrm{CD}^{+} \mathrm{T}$ cells during the chronic stage of infection with LCMV clone 13, particularly for $\mathrm{T}$ cells with high expression of PD-1. In vitro studies have shown that prostaglandin $E_{2}$ inhibits the function of cytotoxic $T$ lymphocytes and strongly suppresses the production of cytokines. Inhibition of the production of prostaglandin $\mathrm{E}_{2}$ with an inhibitor of the cyclooxygenase COX-2 has demonstrated synergy with blockade of PD-1 and improved $\mathrm{T}$ cell function ${ }^{24}$. Our data showed that expression of miR-31 was able to increase expression of the receptor for prostaglandin $\mathrm{E}_{2}$ in $\mathrm{CD} 8^{+} \mathrm{T}$ cells following stimulation with type I interferons. Delineation of the dysfunction signature of tumorinfiltrating $\mathrm{CD}^{+} \mathrm{T}$ cells at the single-cell level has demonstrated that metallothioneins substantially contribute to $\mathrm{T}$ cell dysfunction. Metallothionein-deficient mice have a significantly lower tumor burden and stronger $\mathrm{CD} 8^{+} \mathrm{T}$ cell function than that of metallothionein-sufficient mice ${ }^{25}$. Both $M t 1$ and $M t 2$ (which encode metallothioneins) had

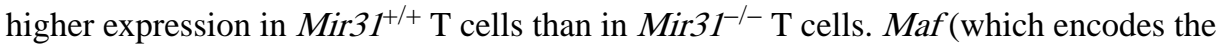
proto-oncoprotein c-Maf) has also been shown to be overexpressed by $\mathrm{T}$ cells during the chronic stage of infection with LCMV clone 13 (ref. 1). However, the expression of several $\mathrm{T}$ cell effector molecules was higher in Mir31-/- $\mathrm{T}$ cells than in Mir $31^{+/+} \mathrm{T}$ cells, particularly following exposure to type I interferons. Such data explain the enhanced functionality of $\mathrm{CD}^{+} \mathrm{T}$ cells in $\mathrm{Mir} 31^{-/-}$mice and the improved clinical course following infection with LCMV clone 13.

Consistent with our findings for mice, stimulation via the TCR induces miR-31 expression in human $\mathrm{T}$ cells ${ }^{46}$. Blocking miR-31 expression in human $\mathrm{T}$ cells might prove 
therapeutically useful for boosting immune responses during chronic viral infection. Moreover, miR-31 might also contribute to human autoimmune conditions characterized by strong signaling via type I interferons, such as systemic lupus erythematosus ${ }^{47}$. Low expression of miR-31 by circulating $\mathrm{T}$ cells has been associated with systemic lupus erythematosus ${ }^{48}$, which suggests that $\mathrm{T}$ cells might escape exhaustion and promote autoimmunity through low expression of miR-31. Finally, the function of miR-31 might also be relevant to cancer, in which $\mathrm{T}$ cell dysfunction represents a substantial block to antitumor immunity.

\section{ONLINE METHODS}

\section{Animals}

C57BL/6J mice, C57BL/6-Tg(Zp3-cre)93Knw/J mice, Tg(Cd4-cre)1Cwi/BfluJ (CD4-cre) mice and C57BL/6-Tg(TcraTcrb)1100Mjb/J (OT-I) mice were obtained from Jackson Laboratories. Mir3 $I^{\mathrm{fl} / \mathrm{fl}}$ conditional knockout mice were produced on the C57BL/6J background at the Brigham and Women's Hospital Transgenic Core Facility. Complete or conditional Mir31-knockout mice were produced by crossing Mir3 $1^{\mathrm{fl} / \mathrm{fl}}$ mice to Zp3-cre (complete) or $C D 4-c r e$ (conditional) knockout strains. All mice were maintained in specificpathogen-free barrier facilities at the Dana-Farber Cancer Institute or at Charles River Laboratories. All experiments were performed in compliance with federal laws and institutional guidelines and were approved by the Animal Care and Use Committee of the Dana-Farber Cancer Institute (Protocol \#04-103).

\section{Infection}

Age- and sex-matched mice were infected intravenously with LCMV clone $13\left(1 \times 10^{6}\right.$ plaque-forming units). LCMV clone 13 was propagated on BHK cells as previously described ${ }^{49}$. After infection, mice were weighed daily, and body weight was calculated as a percentage of initial weight on day 0 . Illness scores were measured by assignment of score of 1 point for each of the following conditions: ruffled fur, hunched back, visually lethargic, lethargic to touch and weight loss exceeding 15\% (ref. 50). Viral load was assayed in serum by plaque assay on Vero cells and in tissues by qRT-PCR for viral GP RNA as described ${ }^{49}$. For infection with influenza virus, age- and sex-matched mice were anesthetized by intraperitoneal injection of $2.5 \%$ Avertin (Sigma-Aldrich) and were infected intranasally with recombinant influenza virus expressing the LCMV glycoprotein peptide of amino acids 33-41 (GP33-41; X31-GP33; $1.6 \times 10^{5}$ TCID $_{50}$ ). Recombinant influenza virus containing the LCMV GP33-41 epitope inserted into the neuraminidase protein stalk region was provided by R. Webby (St. Jude Children's Research Hospital, Memphis, TN) ${ }^{51-53}$. These recombinant influenza virus strains replicate and exhibit pathogenicity similar to that of their non-recombinant counterparts ${ }^{52}$. Viral titers in lungs were determined by qPCR as described ${ }^{51}$.

\section{Flow cytometry}

Cells were stained with the following monoclonal antibodies: (all from BioLegend; dilutions in parentheses): anti-CD69 (H1.2F3) (1:100), anti-CD25 (PC61) (1:200), anti-KLRG1 (2F1/ KLRG1) (1:200), anti-PD-1 (29F.1A12) (1:200), anti-CD8 (53-6.7) (1:400), anti-CD62L 
(MEL-14) (1:200), anti-CD44 (IM7) (1:400), anti-GITR (YGITR 765) (1:100), anti-CD3 (clone 17A2) (1:400) anti-CD11b (clone M1/70) (1:200), anti-CD11c (clone N418) (1:200) anti-granzyme-B (GB11) (1:100), anti-IFN $\gamma$ (XMG1.2) (1:100), anti-TNF (MP6-XT22) (1:100), anti-IL-2 (JES6-5H4) (1:100) and anti-FOXP3 (MF-14) (1:100). For LCMV experiments, cells were stained with dextramers of GP33-41 peptide (KAVYNFATC) bound to $\mathrm{H}-2 \mathrm{D}^{\mathrm{b}}$ (Immudex). For experiments with influenza virus, cells were stained with $\mathrm{H}-2 \mathrm{D}^{\mathrm{b}}$ tetramers loaded with GP33 peptide (KAVYNFATC), NP peptide (ASNENMDAM) or PA peptide (SSLENFRAYV) as described ${ }^{54}$. For intracellular cytokine staining, splenocytes were incubated in complete RPMI medium for $5 \mathrm{~h}$ with no peptide, $10 \mu \mathrm{g} / \mathrm{ml} \mathrm{LCMV}$ GP33-41 (KAVYNFATC), GP276-286 (SGVENPGGYCL), NP396-404 (FQPQNGQFI) or $50 \mathrm{ng} / \mathrm{ml}$ PMA (phorbol-12-myristate-13-acetate) and $500 \mathrm{nM}$ ionomycin in the presence of $5 \mu \mathrm{g} / \mathrm{ml}$ brefeldin A. Intracellular staining was performed using a BD Cytofix/Cytoperm kit according to the manufacturer's instructions. For staining of transcription factors, cells were stained and permeabilized with Foxp3 / Transcription Factor Staining Buffer Set (Biolegend) according to manufacturer's instructions. Data was acquired on a BD Fortessa, and cells were sorted on FACSAria II and III instruments (BD Biosciences). All data were analyzed with FlowJo software (Treestar).

\section{Isolation of immune cell subsets}

For in vitro activation, total or naive $\mathrm{CD} 8^{+} \mathrm{T}$ cells were isolated by negative selection using EasySep beads (Stemcell technologies, Vancouver, BC, Canada). B cells and NK cells were isolated from mouse spleen and peripheral lymph nodes by flow cytometry. B cells were sorted as $\mathrm{CD} 19^{+} \mathrm{B} 220^{+}$and $\mathrm{NK}$ cells were sorted as $\mathrm{DX}^{+} \mathrm{CD}^{-}$. For miRNA profiling, $\mathrm{T}$ cell populations were isolated from spleen and peripheral lymph nodes by flow cytometry. Naive and memory cells were sorted on the basis of the following markers: naive (CD4 ${ }^{+}$or $\left.\mathrm{CD} 8{ }^{+}, \mathrm{CD}_{2} 2 \mathrm{~L}^{+} \mathrm{CD} 44^{10} \mathrm{CD} 25^{+}\right)$, central memory $\left(\mathrm{CD} 4^{+}\right.$or $\left.\mathrm{CD} 8^{+}, \mathrm{CD} 62 \mathrm{~L}^{+} \mathrm{CD} 44^{+} \mathrm{CD} 25^{-}\right)$ and effector memory $\left(\mathrm{CD} 4^{+}\right.$or $\left.\mathrm{CD} 8^{+}, \mathrm{CD}_{2} \mathrm{~L}^{-} \mathrm{CD} 44^{+} \mathrm{CD} 25^{-}\right)$. Regulatory $\mathrm{T}$ cells were sorted as $\mathrm{CD}^{+} \mathrm{CD} 25^{+} \mathrm{GITR}^{+}$. In vivo-activated $\mathrm{CD} 8^{+}$cells were sorted as $\mathrm{CD} 8{ }^{+} \mathrm{CD} 25^{+}$. T cells activated by co-culture with DCs were purified by flow cytometry as $\mathrm{CD}^{+}{ }^{+} \mathrm{CD} 8^{+} \mathrm{CD} 11 \mathrm{~b}^{-} \mathrm{CD} 11 \mathrm{c}^{-} .7678 \mathrm{~T}$ hybridoma cells were isolated as described ${ }^{55}$.

\section{LCMV antibody ELISA}

LCMV antibody titers were determined for serum samples using Smart-M15 enzyme linked immunosorbent assay (Biotech Trading Partners) according to the manufacturer's instructions.

\section{Cell culture and activation}

Cells were cultured in RPMI-1640 medium supplemented with 10\% FCS, 50 units/ml penicillin-streptomycin, $10 \mathrm{mM}$ HEPES, $2 \mathrm{mM}$-glutamine and $55 \mu \mathrm{M} \beta$-mercaptoethanol ('RPMI-10 medium'; all from GIBCO, Carlsbad, CA, USA) at $37{ }^{\circ} \mathrm{C}$ with $5 \% \mathrm{CO}_{2}$. T cells were activated with $10 \mu \mathrm{g} / \mathrm{ml}$ plate-bound CD3 (clone 17A2) with or without $2 \mu \mathrm{g} / \mathrm{ml}$ soluble CD28 antibody (clone 37.51) (both from eBioscience, San Diego, CA, USA), or 500 $\mathrm{nM}$ ionomycin. Cyclosporin A was added at $250 \mathrm{ng} / \mathrm{ml}$. NK cells were activated with PMA

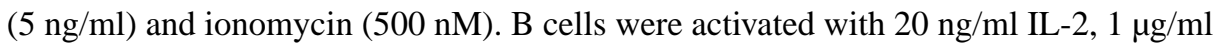
polyclonal goat $\mathrm{F}\left(\mathrm{ab}^{\prime}\right)_{2}$ antibody to mouse IgM (Southern Biotech, Birmingham, AL, USA, 
product number 1022-01) and $3 \mu \mathrm{g} / \mathrm{ml} \mathrm{CpG} \mathrm{2006.} \mathrm{OT-I} \mathrm{CD}{ }^{+} \mathrm{T}$ cells were activated with splenocytes pulsed with ovalbumin peptide (amino acids 257-264) in the presence of 20 $\mathrm{ng} / \mathrm{ml} \mathrm{IL}-2$. For type I interferon treatment, cells were incubated with $20 \mathrm{ng} / \mathrm{ml}$ (or as indicated in the text) of recombinant mouse IFN $\beta 1$ (BioLegend).

To generate DCs, bone marrow cells were isolated from the femurs of C57BL/6 mice, red blood cells were lysed (ACK Lysis Buffer, Gibco) at RT for 5 min and washed, and cells were resuspended in RPMI-1640 (10\% FBS and 1\% penicillin-streptomycin) supplemented with $20 \mathrm{ng} / \mathrm{ml}$ murine GM-CSF (Peprotech,) and plated in $10 \mathrm{ml}$ at a final density of $2 \times 10^{5}$ cells $/ \mathrm{ml}$ in $10-\mathrm{cm}$ Petri dishes and incubated at $37{ }^{\circ} \mathrm{C} 5 \% \mathrm{CO}_{2}$. After $2 \mathrm{~d}, 10 \mathrm{ml}$ of additional supplemented RMPI-1640 was added. $2 \mathrm{~d}$ later, half of the medium was removed and replenished with supplemented RMPI-1640. After $4 \mathrm{~d}$ of further incubation, DCs were stimulated with $1 \mu \mathrm{g} / \mathrm{ml}$ lipopolysaccharide (Sigma-Aldrich) and pulsed with $100 \mathrm{pM}$ ovalbumin peptide (SIINFEKL) (Sigma) overnight. For T cell-activation assays, DCs were then washed, irradiated (2,500 rads), washed, and added to $\mathrm{T}$ cells at the indicated ratio.

\section{NFAT1 chromatin immunoprecipitation}

For NFAT1 chromatin-immunoprecipitation experiments, $\mathrm{P} 14^{+} \mathrm{TCRa}^{-/}$cells were plated at $1 \times 10^{6}$ cells $/ \mathrm{ml}$ in six-well plates coated with anti-CD3 (clone $2 \mathrm{C} 11$; purified by the A.R. laboratory) and anti-CD28 (clone 37.51; BD-Pharmingen) $(1 \mu \mathrm{g} / \mathrm{ml}$ each) by pre-coating with $300 \mu \mathrm{g} / \mathrm{ml}$ goat anti-hamster IgG (catalog 56984; Cappel). After $48 \mathrm{~h}$, cells were removed from the TCR signal and were re-cultured at a density of $5 \times 10^{5} \mathrm{cells} / \mathrm{ml}$ in media supplemented with $10 \mathrm{U} / \mathrm{ml}$ recombinant human IL-2 (rhIL-2). Every $24 \mathrm{~h}$, cells were counted and readjusted to $5 \times 10^{5}$ cells $/ \mathrm{ml}$ with fresh media containing rhIL-2. On day 6 , cells were either left untreated (resting), or re-stimulated with phorbol 12-myristate 13acetate (PMA; $15 \mathrm{nM}$; Sigma) and ionomycin (1 $\mu \mathrm{M}$; Sigma). The protocol for chromatin immunoprecipitation of NFAT1 and computational analysis have been described in detail ${ }^{56}$ and genome-scale data are available ${ }^{14}$ The transcription start site for the mouse host gene encoding miR-31 was identified as mm9: chr4:88584380 based on homology to the transcription start site of the human host gene encoding miR-31 (MIR31HG) ${ }^{57}$, histone $\mathrm{H} 3 \mathrm{~K} 4 \mathrm{~m} 3$ methylation in liver and kidney by ENCODE/LICR ${ }^{58}$, and spliced expressed sequence tags observed in Mir31-l- $\mathrm{CD}^{+}$T-cells (data not shown).

\section{miRNA-specific RT-PCR assay}

The synthesis of miRNA specific cDNA from total RNA was carried out using MicroRNA Reverse Transcription Kit (Applied Biosystems, Carlsbad, CA, USA). MiRNA-specific RTPCRs were performed using Taqman miRNA assays according to the manufacturer's protocol (Applied Biosystems, Carlsbad, CA, USA). MiRNA expression was calculated using the $\Delta \Delta \mathrm{Ct}$ method using miR-16 or the $\Delta \mathrm{Ct}$ method using sno234 as expression standards.

\section{Lentiviral vectors}

Lentiviral vectors driving expression of shRNAs directed against the luciferase-encoding gene and mouse Lats2, Ppp6c, Stk4O and Sh2d1a were obtained from the RNAi Consortium and subcloned into the pLKO.3G vector. miR-31 precursor sequence was generated by 
primer extension and was cloned into the pLKO.3G vector. shRNA directed against the luciferase-encoding gene or empty pLKO.3G constructs were used as controls for infection. The cloned mir-31 hairpin sequence is TGCTCCTGTAACTCGGAACTGGAGAG GAGGCAAGATGCTGGCATAGCTGTTGAACTGAGAACCTGCTATGCCA ACATATTGCCATCTTTCCTGTCTGACAGCAGCTTGGCTACCTC.

Constitutively active NFAT1 has been described ${ }^{59}$ and was subcloned from Addgene plasmid 11792 into the pHAGE lentiviral vector for mammalian expression. Empty pHAGE lentiviral vector was used as an infection control.

\section{miRNA expression profiling}

We profiled 279 miRNAs by the Luminex method as described ${ }^{60}$. Profiling data were normalized by generating a mean array for the expression of each miRNA in all samples. Next, a linear correction for each sample to the mock array was performed. Hierarchical clustering was performed using GenePattern software from the Broad Institute ${ }^{61}$.

\section{Microarray profiling and miR-31 target gene prediction}

$\mathrm{CD} 8^{+} \mathrm{T}$ cells were purified from OT-I mice by negative selection and were cultured for $2 \mathrm{~d}$ in RPMI-10 with $100 \mathrm{ng} / \mathrm{ml} \mathrm{IL-15}$ and $1 \mathrm{ng} / \mathrm{ml} \mathrm{IL-7} \mathrm{(R \& D} \mathrm{Systems,} \mathrm{Minneapolis,} \mathrm{MN,}$ USA). Cells were infected with empty or miR-31-expressing pLKO.3G lentiviral vector at a multiplicity of infection of 10:1 by spin-infection in Retronectin-coated plates (Takara Bio, Otsu, Shiga, Japan). After infection, cells were cultured for 3 additional days in RPMI-10 with $10 \mathrm{ng} / \mathrm{ml} \mathrm{IL-2} \mathrm{(R \& D} \mathrm{Systems).} \mathrm{GFP}{ }^{+}$cells from four independent cultures per condition were then sorted by flow cytometry and RNA was isolated using Trizol followed by cleanup with RNeasy columns (Qiagen Valencia, CA, USA). $10 \mu \mathrm{g}$ RNA per condition was profiled on Affymetrix Mouse Genome 4302.0 Arrays. Array data analysis was performed using DCHIP including absent/present calls. For probes with $100 \%$ present calls in at least one group $(22,864)$, we identified differentially expressed genes using Significance Analysis of Microarrays using standard test statistics and a delta value of 0.582 (refs. 62,63). A master list of miR-31 target genes was generated using the union of mouse miR-31 target predictions from Targetscan, Starbase, Rna22, Pictar and Miranda ${ }^{64-68}$. To generate matching null distributions for down- or upregulated gene sets, $1 \times 10^{4}$ sets of 119 probes or 432 probes were randomly selected from expressed but not differentially regulated probes, and the frequency of predicted miR-31 targets in each set was calculated. Analysis of statistically associated upstream regulators of differentially expressed genes was performed with Ingenuity Pathway Analysis using standard settings. Microarray data were deposited in the GEO database.

\section{Immunoblot analysis}

Cells were lysed in RIPA buffer (Cell Signaling Technology, Danvers MA, USA) in the presence of protease inhibitor cocktail (Roche, Basel, Switzerland). Lysed material was clarified by centrifugation at $12,000 \mathrm{~g}$ for $10 \mathrm{~min}$ at $4{ }^{\circ} \mathrm{C}$. Clarified extracts representing $30 \times$ $10^{5}$ cells per lane were fractionated on a $10 \%$ Bis-Tris gel and transferred to a polyvinylidene difluoride membrane using a transfer apparatus according to the manufacturer's protocol (Bio-Rad, Hercules, CA, USA). Membranes were blocked for $1 \mathrm{~h}$ 
with $5 \%$ nonfat milk in TBST (10 mM Tris, $\mathrm{pH} 8.0,150 \mathrm{mM} \mathrm{NaCl}$ abd $0.5 \%$ Tween 20 ).

Membranes were washed $1 \times$ in TBST, and incubated with anti- $\beta$-actin (clone 13E5, 1:1000 dilution, Cell Signaling Technology, Danvers MA, USA) and anti-PPP6C (clone ab131335, 1:1000 dilution, Abcam, Cambridge, United Kingdom) for $18 \mathrm{~h}$ at $4{ }^{\circ} \mathrm{C}$. Membranes were washed three times with TBST and were incubated with a 1:2,500 dilution of horseradish peroxidase-conjugated polyclonal goat antibody to rabbit (catalog number 7074; Cell Signaling Technology, Danvers MA, USA) for $1 \mathrm{~h}$ at RT. Membranes were washed three times with TBST, developed with the ECL system (Amersham Biosciences) and visualized on a ChemiDoc imaging system (Bio-Rad, Hercules, CA, USA) per the manufacturer's protocols. Full images and size marker standards are presented in Supplementary Figure 6.

\section{Luciferase reporter assay}

$3^{\prime}$ UTR sequences containing predicted target sites and at least 500 base pairs of flanking sequence were cloned downstream of a firefly luciferase reporter in the pcDNA3.1 mammalian expression vector. 293T cells were transfected in a 96-well format with $20 \mu \mathrm{g}$ Firefly luciferase reporter containing no 3' UTR (Control) or test 3' UTRs, $20 \mu \mathrm{g}$ control pcDNA3.1 Renilla luciferase reporter, and $200 \mu \mathrm{g}$ of control or miR-31 pLKO.3G vector. Luciferase activity was quantified at $24 \mathrm{~h}$ with DualGlo reagents (Promega, Madison, WI, USA).

\section{Type I interferon stimulation of activated $C^{2} 8^{+} \mathrm{T}$ cells}

$\mathrm{CD} 8^{+} \mathrm{T}$ cells were isolated by negative selection (EasySep CD8 Negative Isolation Kit, Stem Cell) from the spleens and lymph nodes of wild-type and Mir $31^{-1-}$ mice and were resuspended in RPMI-10 at a density of $1.5 \times 10^{6} \mathrm{cells} / \mathrm{ml}$. T cells were then incubated with beads coated with anti-CD3 and anti-CD28 (Dynabeads, Thermo Scientific) at a ratio of 2:1 in RPMI- 10 at $37{ }^{\circ} \mathrm{C}$ and $5 \% \mathrm{CO}_{2}$ for $48 \mathrm{~h}$. After $48 \mathrm{~h}$, beads were removed using a magnetic column (EasySep Magnet; Stem Cell) and the cells were cultured in RPMI-10 supplemented with $10 \mathrm{ng} / \mathrm{ml}$ of IL-2 for $5 \mathrm{~d}$. Supplemented medium was replenished as required to maintain a cell density of $1.5 \times 10^{6} \mathrm{cells} / \mathrm{ml}$. After $7 \mathrm{~d}$ of culture, T cells were washed and stimulated in RPMI-10 supplemented with $20 \mathrm{ng} / \mathrm{ml}$ IFN- $\beta$ (BioLegend) for either 0,10 , and $30 \mathrm{~min}$ (immunoblot analysis) or 0,4 and $18 \mathrm{~h}$ (qPCR or flow cytometry).

For immunoblot analysis sample preparation, cells were counted, and equal numbers from each condition were lysed at each time point in RIPA buffer (Sigma-Aldrich) supplemented with $50 \mathrm{mM} \mathrm{NaF}$, protease inhibitor cocktail (P8340, Sigma) and $0.2 \mathrm{mM}$ sodium orthovanadate. Lysates were incubated at $4{ }^{\circ} \mathrm{C}$ for $10 \mathrm{~min}$, then running buffer (NuPAGE LDS Sample Buffer, Thermo) was added at a final concentration of $1 \times$, then the sample was heated at $70{ }^{\circ} \mathrm{C}$ for $5 \mathrm{~min}$ and then stored at $4{ }^{\circ} \mathrm{C}$. Lysate equivalent to $1 \times 10^{5}$ cells was loaded per lane onto TGX gels (Bio-Rad) for fluorescence-based detection of total proteins based on the manufacturer's recommendations ( $45 \mathrm{~s} \mathrm{UV} \mathrm{light} \mathrm{treatment} \mathrm{followed} \mathrm{by} \mathrm{UV}$ trans-illumination adjusted for optimal signal intensity). A central section of the gel was used for quantification. This total protein signal was used to normalize STAT1 immunoblot signals. 
For RNA analysis, RNA was extracted at each time point using a Directzol RNA Mini-Prep Kit (Zymo Research) per manufacturer's instructions. For RNA-seq analysis, libraries were generated using Illumina stranded mRNA library prep and sequencing using Illumina NS500 Single-End 75bp sequencing. Statistical significance was determined using VIPER analysis. For qPCR analysis, first strand synthesis was then performed using a SuperScript VILO cDNA synthesis kit (Thermo Fisher Scientific), and qPCR was performed using TaqMan Gene Expression Master Mix (Thermo Fisher Scientific) and primer/probes targeted for Gapdh (Mm99999915_g1), STAT1 (Mm0257286_m1), STAT2 (Mm00490880_m1), IRF9 (Mm00492679_m1), SOCS1 (Mm00782550_s1), Mt1 (Mm00496660_g1), Mt2 (Mm00809556_s1), Maf (Mm02581355_s1), Il7r (Mm00434295_m1), Ptger2 (Mm00436051_m1), Spp1 (Mm00436767_m1), Gzmb (Mm00442837_m1), Gzmd (Mm01722569_g1) and Prf1 (Mm00812512_m1) on a C1000 Touch Thermal Cycler (Bio$\mathrm{Rad})$.

For flow cytometry, cells were stained for surface markers (CD8-BV786, clone 53-6.7, BioLegend) in flow cytometry buffer (5\% FBS in $1 \mathrm{X}$ PBS) for $30 \mathrm{~min}$ at $4{ }^{\circ} \mathrm{C}$. Cells were fixed in $4 \%$ paraformaldehyde for $20 \mathrm{~min}$, washed, permeabilized for $20 \mathrm{~min}$ (Cytofix/ Cytoperm; BD Biosciences) and stained for $30 \mathrm{~min}$ at $4{ }^{\circ} \mathrm{C}$ for intracellular markers (granzyme C-PE, clone SFC1D8, BioLegend; perforin, clone eBioMAK-D, eBioscience). All antibodies were used at a dilution of 1:1000. Cells were then washed in flow cytometry buffer and analyzed by flow cytometry (BD LSR Fortessa X20).

\section{Statistical analysis}

Statistical analysis was performed using Prism software (Graph Pad) unless otherwise stated in figure legends. Unpaired, two-tailed Student's $t$-tests were used for comparison of two groups. Two-way ANOVA with Sidak corrections for multiple comparisons was used for comparisons of more than two groups. For gene-set-enrichment analysis, the false-discovery rate (FDR) $q$ value was calculated using the Gene Set Enrichment Analysis software (Broad Institute, MA, USA). Significance was set at $P<0.05$.

\section{Data availability}

The data that support the findings of this study are available from the corresponding author upon request. Data have been deposited in the GEO database with the following accession codes: microarray, GSE63549; ChIP-seq (chromatin immunoprecipitation followed by deep sequencing), GSE90707; and RNA-seq, GSE98615.

\section{Supplementary Material}

Refer to Web version on PubMed Central for supplementary material.

\section{Acknowledgments}

We thank R. Webby (St. Jude Children's Research Hospital) for recombinant influenza virus containing the LCMV GP33-41 epitope inserted into the neuraminidase protein stalk region; J. Maiarana for technical assistance; and the Dana Farber Cancer Institute Molecular Biology Core Facility for RNA sequencing. Supported by the US National Institutes of Health (R01CA173750 to K.W.W.; R01DK102165 and R01CA140986 to C.N.; P01AI056299 to A.S.; and R01AI007386 to H.C.) and the Cancer Research Institute (A.N.R.C.). 


\section{References}

1. Wherry EJ, et al. Molecular signature of $\mathrm{CD}^{+} \mathrm{T}$ cell exhaustion during chronic viral infection. Immunity. 2007; 27:670-684. [PubMed: 17950003]

2. Muljo SA, et al. Aberrant T cell differentiation in the absence of Dicer. J Exp Med. 2005; 202:261269. [PubMed: 16009718]

3. Cobb BS, et al. T cell lineage choice and differentiation in the absence of the RNase III enzyme Dicer. J Exp Med. 2005; 201:1367-1373. [PubMed: 15867090]

4. Zhang N, Bevan MJ. Dicer controls $\mathrm{CD}^{+}$T-cell activation, migration, and survival. Proc Natl Acad Sci USA. 2010; 107:21629-21634. [PubMed: 21098294]

5. Wu T, et al. Temporal expression of microRNA cluster miR-17-92 regulates effector and memory $\mathrm{CD}^{+}$T-cell differentiation. Proc Natl Acad Sci USA. 2012; 109:9965-9970. [PubMed: 22665768]

6. Yang L, et al. miR-146a controls the resolution of T cell responses in mice. J Exp Med. 2012; 209:1655-1670. [PubMed: 22891274]

7. Taganov KD, Boldin MP, Chang KJ, Baltimore D. NF- $\kappa$ B-dependent induction of microRNA miR-146, an inhibitor targeted to signaling proteins of innate immune responses. Proc Natl Acad Sci USA. 2006; 103:12481-12486. [PubMed: 16885212]

8. Gracias DT, et al. The microRNA miR-155 controls $\mathrm{CD} 8^{+} \mathrm{T}$ cell responses by regulating interferon signaling. Nat Immunol. 2013; 14:593-602. [PubMed: 23603793]

9. Lu LF, et al. Foxp3-dependent microRNA155 confers competitive fitness to regulatory $\mathrm{T}$ cells by targeting SOCS1 protein. Immunity. 2009; 30:80-91. [PubMed: 19144316]

10. Trifari S, et al. MicroRNA-directed program of cytotoxic CD8 ${ }^{+}$T-cell differentiation. Proc Natl Acad Sci USA. 2013; 110:18608-18613. [PubMed: 24163352]

11. Bronevetsky Y, et al. T cell activation induces proteasomal degradation of Argonaute and rapid remodeling of the microRNA repertoire. J Exp Med. 2013; 210:417-432. [PubMed: 23382546]

12. Monticelli S, Rao A. NFAT1 and NFAT2 are positive regulators of IL-4 gene transcription. Eur J Immunol. 2002; 32:2971-2978. [PubMed: 12355451]

13. Martinez GJ, et al. The transcription factor NFAT promotes exhaustion of activated $\mathrm{CD} 8^{+} \mathrm{T}$ cells. Immunity. 2015; 42:265-278. [PubMed: 25680272]

14. Scott-Browne JP, et al. Dynamic changes in chromatin accessibility occur in $\mathrm{CD}^{+} \mathrm{T}$ cells responding to viral infection. Immunity. 2016; 45:1327-1340. [PubMed: 27939672]

15. Alexiou P, Maragkakis M, Papadopoulos GL, Reczko M, Hatzigeorgiou AG. Lost in translation: an assessment and perspective for computational microRNA target identification. Bioinformatics. 2009; 25:3049-3055. [PubMed: 19789267]

16. Baek D, et al. The impact of microRNAs on protein output. Nature. 2008; 455:64-71. [PubMed: 18668037]

17. Selbach M, et al. Widespread changes in protein synthesis induced by microRNAs. Nature. 2008; 455:58-63. [PubMed: 18668040]

18. Lim LP, et al. Microarray analysis shows that some microRNAs downregulate large numbers of target mRNAs. Nature. 2005; 433:769-773. [PubMed: 15685193]

19. Wu D, Wang B, Shang J, Song J, Zhang H. miR-31 reduces cell growth of papillary thyroid carcinoma by RNA-binding protein HuR. Clin Lab. 2015; 61:1625-1634. [PubMed: 26731986]

20. Creighton CJ, et al. Molecular profiling uncovers a p53-associated role for microRNA-31 in inhibiting the proliferation of serous ovarian carcinomas and other cancers. Cancer Res. 2010; 70:1906-1915. [PubMed: 20179198]

21. Ivanov SV, et al. Pro-tumorigenic effects of miR-31 loss in mesothelioma. J Biol Chem. 2010; 285:22809-22817. [PubMed: 20463022]

22. Liu X, et al. MicroRNA-31 functions as an oncogenic microRNA in mouse and human lung cancer cells by repressing specific tumor suppressors. J Clin Invest. 2010; 120:1298-1309. [PubMed: 20237410]

23. Rutledge $\mathrm{H}$, et al. Identification of microRNAs associated with allergic airway disease using a genetically diverse mouse population. BMC Genomics. 2015; 16:633. [PubMed: 26303911] 
24. Chen JH, et al. Prostaglandin E2 and programmed cell death 1 signaling coordinately impair CTL function and survival during chronic viral infection. Nat Med. 2015; 21:327-334. [PubMed: 25799228]

25. Singer M, Wang C, Cong L, Marjanovic ND, Kowalczyk MS, Zhang H, et al. A distinct gene module for dysfunction uncoupled from activation in tumor-infiltrating T cells. Cell. 2016; 166:1500-1511. [PubMed: 27610572]

26. Ivashkiv LB, Donlin LT. Regulation of type I interferon responses. Nat Rev Immunol. 2014; 14:36-49. [PubMed: 24362405]

27. McNally JM, et al. Attrition of bystander CD8 T cells during virus-induced T-cell and interferon responses. J Virol. 2001; 75:5965-5976. [PubMed: 11390598]

28. Marshall HD, Urban SL, Welsh RM. Virus-induced transient immune suppression and the inhibition of T cell proliferation by type I interferon. J Virol. 2011; 85:5929-5939. [PubMed: 21471240]

29. Terawaki S, et al. IFN-a directly promotes programmed cell death-1 transcription and limits the duration of T cell-mediated immunity. J Immunol. 2011; 186:2772-2779. [PubMed: 21263073]

30. Stefansson B, Brautigan DL. Protein phosphatase PP6 N terminal domain restricts G1 to S phase progression in human cancer cells. Cell Cycle. 2007; 6:1386-1392. [PubMed: 17568194]

31. Kajino T, et al. Protein phosphatase 6 down-regulates TAK1 kinase activation in the IL-1 signaling pathway. J Biol Chem. 2006; 281:39891-39896. [PubMed: 17079228]

32. Lee MN, et al. Identification of regulators of the innate immune response to cytosolic DNA and retroviral infection by an integrative approach. Nat Immunol. 2013; 14:179-185. [PubMed: 23263557]

33. Barber DL, et al. Restoring function in exhausted CD8 T cells during chronic viral infection. Nature. 2006; 439:682-687. [PubMed: 16382236]

34. Teijaro JR, et al. Persistent LCMV infection is controlled by blockade of type I interferon signaling. Science. 2013; 340:207-211. [PubMed: 23580529]

35. Wilson EB, et al. Blockade of chronic type I interferon signaling to control persistent LCMV infection. Science. 2013; 340:202-207. [PubMed: 23580528]

36. Punkosdy GA, et al. Regulatory T-cell expansion during chronic viral infection is dependent on endogenous retroviral superantigens. Proc Natl Acad Sci USA. 2011; 108:3677-3682. [PubMed 21321220]

37. Penaloza-MacMaster P, et al. Interplay between regulatory T cells and PD-1 in modulating T cell exhaustion and viral control during chronic LCMV infection. J Exp Med. 2014; 211:1905-1918. [PubMed: 25113973]

38. Rouas R, et al. Human natural Treg microRNA signature: role of microRNA-31 and microRNA-21 in FOXP3 expression. Eur J Immunol. 2009; 39:1608-1618. [PubMed: 19408243]

39. Zhang L, et al. MicroRNA-31 negatively regulates peripherally derived regulatory T-cell generation by repressing retinoic acid-inducible protein 3. Nat Commun. 2015; 6:7639. [PubMed: 26165721]

40. Xue F, et al. miR-31 regulates interleukin 2 and kinase suppressor of ras 2 during $\mathrm{T}$ cell activation. Genes Immun. 2013; 14:127-131. [PubMed: 23303246]

41. Fan W, et al. Identification of microRNA-31 as a novel regulator contributing to impaired interleukin-2 production in T cells from patients with systemic lupus erythematosus. Arthritis Rheum. 2012; 64:3715-3725. [PubMed: 22736314]

42. Wang Y, et al. Timing and magnitude of type I interferon responses by distinct sensors impact CD8 T cell exhaustion and chronic viral infection. Cell Host Microbe. 2012; 11:631-642. [PubMed: 22704623]

43. Bahl K, et al. IFN-induced attrition of CD8 T cells in the presence or absence of cognate antigen during the early stages of viral infections. J Immunol. 2006; 176:4284-4295. [PubMed: 16547266]

44. Marshall HD, Urban SL, Welsh RM. Virus-induced transient immune suppression and the inhibition of T cell proliferation by type I interferon. J Virol. 2011; 85:5929-5939. [PubMed: 21471240]

45. Terawaki $\mathrm{S}$, et al. IFN-a directly promotes programmed cell death-1 transcription and limits the duration of T cell-mediated immunity. J Immunol. 2011; 186:2772-2779. [PubMed: 21263073] 
46. Xue F, et al. miR-31 regulates interleukin 2 and kinase suppressor of ras 2 during $\mathrm{T}$ cell activation. Genes Immun. 2013; 14:127-131. [PubMed: 23303246]

47. Crow MK. Type I interferon in the pathogenesis of lupus. J Immunol. 2014; 192:5459-5468. [PubMed: 24907379]

48. Fan W, et al. Identification of microRNA-31 as a novel regulator contributing to impaired interleukin-2 production in T cells from patients with systemic lupus erythematosus. Arthritis Rheum. 2012; 64:3715-3725. [PubMed: 22736314]

49. Welsh RM, Seedhom MO. Lymphocytic choriomeningitis virus (LCMV): propagation, quantitation, and storage. Current Protocols in Microbiology. 2008; Ch 15(Unit 15A):11.

50. Stamm A, Valentine L, Potts R, Premenko-Lanier M. An intermediate dose of LCMV clone 13 causes prolonged morbidity that is maintained by CD4+ T cells. Virology. 2012; 425:122-132. [PubMed: 22305620]

51. Laidlaw BJ, et al. Cooperativity between $\mathrm{CD}^{+} \mathrm{T}$ cells, non-neutralizing antibodies, and alveolar macrophages is important for heterosubtypic influenza virus immunity. PLoS Pathog. 2013; 9:e1003207. [PubMed: 23516357]

52. Decman V, et al. Cell-intrinsic defects in the proliferative response of antiviral memory CD8 T cells in aged mice upon secondary infection. J Immunol. 2010; 184:5151-5159. [PubMed: 20368274]

53. Mueller SN, et al. Qualitatively different memory $\mathrm{CD}^{+} \mathrm{T}$ cells are generated after lymphocytic choriomeningitis virus and influenza virus infections. J Immunol. 2010; 185:2182-2190. [PubMed: 20639484]

54. Wherry EJ, Blattman JN, Murali-Krishna K, van der Most R, Ahmed R. Viral persistence alters CD8 T-cell immunodominance and tissue distribution and results in distinct stages of functional impairment. J Virol. 2003; 77:4911-4927. [PubMed: 12663797]

55. Call MJ, et al. In vivo enhancement of peptide display by MHC class II molecules with small molecule catalysts of peptide exchange. J Immunol. 2009; 182:6342-6352. [PubMed: 19414787]

56. Martinez GJ, et al. The transcription factor NFAT promotes exhaustion of activated $\mathrm{CD} 8^{+} \mathrm{T}$ cells. Immunity. 2015; 42:265-278. [PubMed: 25680272]

57. Kent WJ, et al. The human genome browser at UCSC. Genome Res. 2002; 12:996-1006. [PubMed: 12045153]

58. Rosenbloom KR, et al. ENCODE data in the UCSC Genome Browser: year 5 update. Nucleic Acids Res. 2013; 41:D56-D63. [PubMed: 23193274]

59. Okamura $\mathrm{H}$, et al. Concerted dephosphorylation of the transcription factor NFAT1 induces a conformational switch that regulates transcriptional activity. Mol Cell. 2000; 6:539-550. [PubMed: 11030334]

60. Lu J, et al. MicroRNA expression profiles classify human cancers. Nature. 2005; 435:834-838. [PubMed: 15944708]

61. Reich M, et al. GenePattern 2.0. Nat Genet. 2006; 38:500-501. [PubMed: 16642009]

62. Schadt EE, Li C, Ellis B, Wong WH. Feature extraction and normalization algorithms for highdensity oligonucleotide gene expression array data. J Cell Biochem Suppl. 2001; 37:120-125. [PubMed: 11842437]

63. Tusher VG, Tibshirani R, Chu G. Significance analysis of microarrays applied to the ionizing radiation response. Proc Natl Acad Sci USA. 2001; 98:5116-5121. [PubMed: 11309499]

64. Miranda KC, et al. A pattern-based method for the identification of MicroRNA binding sites and their corresponding heteroduplexes. Cell. 2006; 126:1203-1217. [PubMed: 16990141]

65. Friedman RC, Farh KK, Burge CB, Bartel DP. Most mammalian mRNAs are conserved targets of microRNAs. Genome Res. 2009; 19:92-105. [PubMed: 18955434]

66. Betel D, Koppal A, Agius P, Sander C, Leslie C. Comprehensive modeling of microRNA targets predicts functional non-conserved and non-canonical sites. Genome Biol. 2010; 11:R90. [PubMed: 20799968]

67. Yang JH, et al. starBase: a database for exploring microRNA-mRNA interaction maps from Argonaute CLIP-Seq and Degradome-Seq data. Nucleic Acids Res. 2011; 39:D202-D209. [PubMed: 21037263] 
68. Krek A, et al. Combinatorial microRNA target predictions. Nat Genet. 2005; 37:495-500. [PubMed: 15806104] 

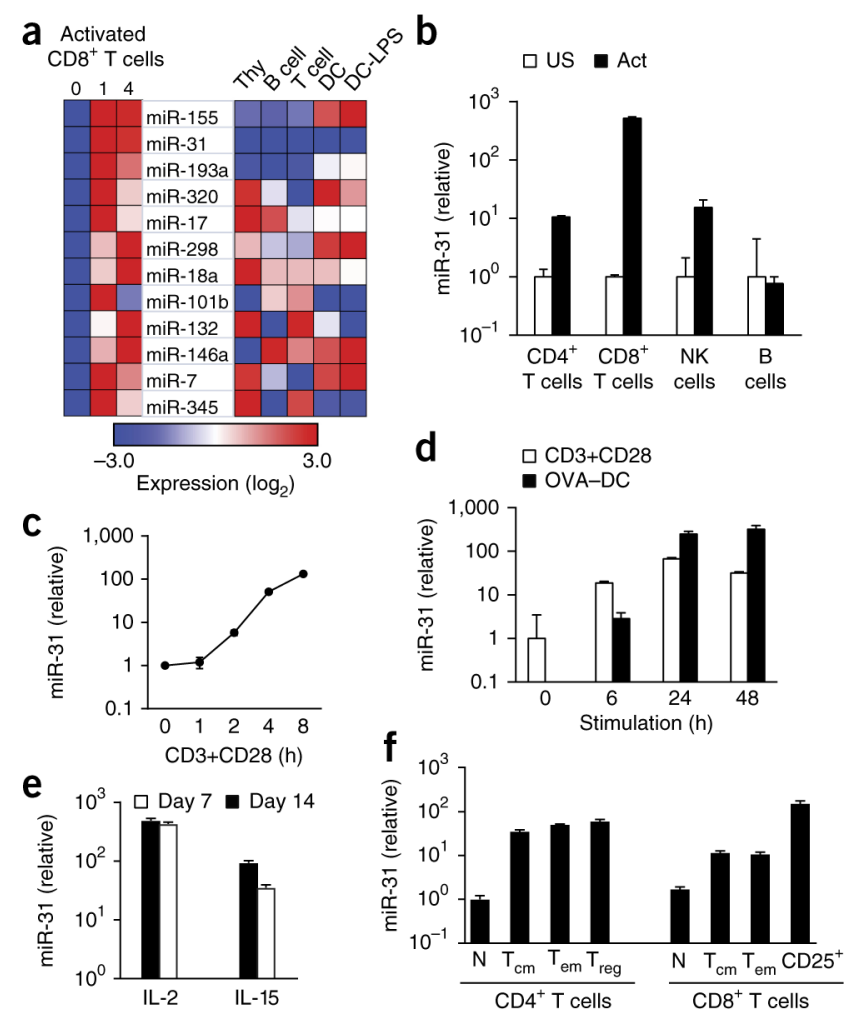

Figure 1.

miR-31 is induced during $\mathrm{T}$ cell activation. (a) miRNAs (middle) with an increase in expression of more than twofold following activation of $\mathrm{CD} 8^{+} \mathrm{T}$ cells for $1-4 \mathrm{~d}$ with antiCD3 plus anti-CD28, relative to that of unstimulated cells (day 0) (left), and expression of those miRNAs in total thymocytes (Thy), B cells, T cells, bone-marrow-derived DCs (DC) and LPS-treated DCs (DC-LPS) (right), presented as row-normalized relative expression $\left(\log _{2}\right.$ ). (b) qPCR analysis of miR-31 in CD4+ or CD8 ${ }^{+} \mathrm{T}$ cells activated (Act) for $24 \mathrm{~h}$ with anti-CD3 plus anti-CD28, NK cells activated for $24 \mathrm{~h}$ with PMA and ionomycin, and B cells activated for $24 \mathrm{~h}$ with an antibody to immunoglobulin $\mathrm{M}$ and $\mathrm{CpG}$; results are presented relative to those of the unstimulated counterparts (US). (c) qPCR analysis of miR-31 in $\mathrm{CD}^{+} \mathrm{T}$ cells activated for $0-8 \mathrm{~h}$ (horizontal axis) with anti-CD3 plus anti-CD28 (CD3+CD28); results are presented relative to those at $0 \mathrm{~h}$. (d) qPCR analysis of mir-31 in OT-I T cells activated for $0-48 \mathrm{~h}$ (horizontal axis) with anti-CD3 plus anti-CD28 (CD3+CD28) or by co-culture with OVA-peptide-pulsed DCs (OVA-DC) (T cell/DC ratio, 1:1) (key); results presented as in c. (e) qPCR analysis of mir-31 in OT-I CD8 ${ }^{+} \mathrm{T}$ cells activated for $48 \mathrm{~h}$ by OVA-peptide-pulsed splenocytes, then treated for 7 or $14 \mathrm{~d}$ (key) with IL-2 or IL-15 (horizontal axis); results are presented relative to those of untreated cells. (f) qPCR analysis of mir-31 in naive $\left(\mathrm{CD} 44^{\mathrm{lo}} \mathrm{CD} 62 \mathrm{~L}^{+}\right) \mathrm{T}$ cells $(\mathrm{N})$, effector memory $\left(\mathrm{CD} 44^{\text {hi }} \mathrm{CD} 6 \mathrm{~L}^{-}\right) \mathrm{T}$ cells $\left(\mathrm{T}_{\mathrm{EM}}\right)$, central memory (CD44hiCD62L+) $\mathrm{T}$ cells $\left(\mathrm{T}_{\mathrm{CM}}\right)$, regulatory $\left(\mathrm{CD} 4{ }^{+} \mathrm{CD} 25^{+} \mathrm{GITR}^{+}\right) \mathrm{T}$ cells $\left(\mathrm{T}_{\text {reg }}\right)$, and activated $\mathrm{CD} 8+\left(\mathrm{CD} 8{ }^{+} \mathrm{CD} 25^{+}\right) \mathrm{T}$ cells $\left(\mathrm{CD} 25^{+}\right.$), with all $\mathrm{CD}^{+}$or $\mathrm{CD} 8^{+}$subsets (horizontal axis) sorted ex vivo; results are presented relative to those of naive $\mathrm{T}$ cells. Data are representative of one experiment (a), three experiments (b; error bars, s.d.) or two experiments (c-f; error bars $(\mathbf{d}-\mathbf{f})$, s.d.). 

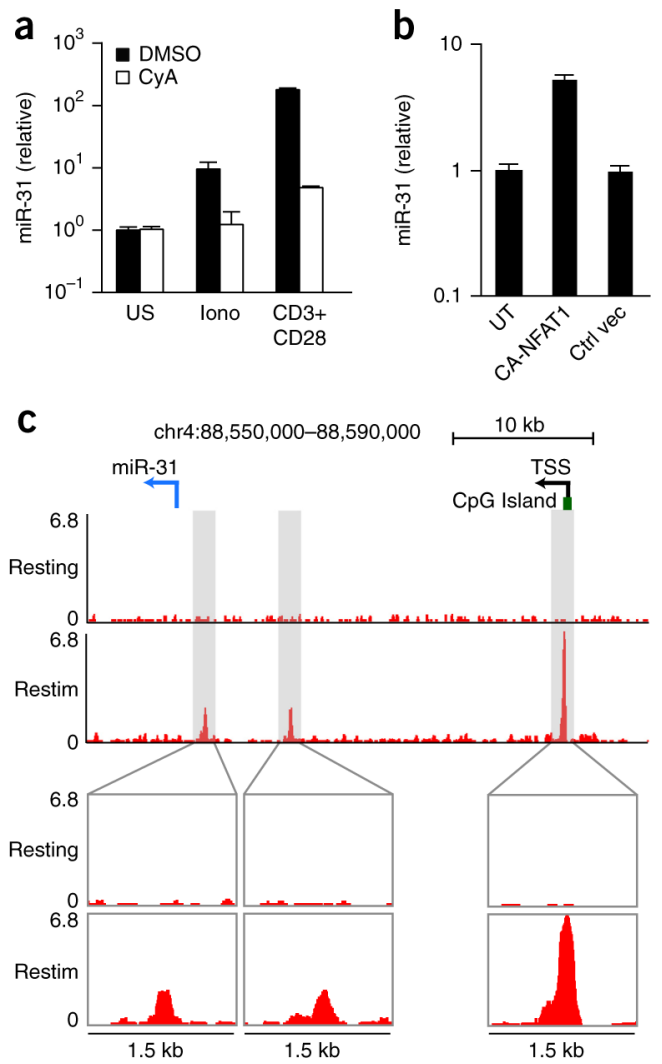

Figure 2.

mir-31 is induced by signaling via calcium and NFAT. (a) qPCR analysis of miR-31 in CD8 ${ }^{+}$ $\mathrm{T}$ cells stimulated for $24 \mathrm{~h}$ with ionomycin (Iono) or with anti-CD3 plus anti-CD28 (horizontal axis) and treated with vehicle (DMSO) or cyclosporin A (CyA) (key); results are presented relative to those of unstimulated cells. (b) qPCR analysis of mR-31 in T cells infected with a lentiviral vector driving expression of constitutively active NFAT1 (CANFAT1) or a control lentiviral vector ( $\mathrm{Ctrl}$ vec); results are presented relative to those of untransduced CD8 ${ }^{+}$T cells (UT). (c) Chromatin-immunoprecipitation analysis of NFAT1 in $\mathrm{CD}^{+} \mathrm{T}$ cells activated with anti-CD3 plus anti-CD28, followed by population expansion for $6 \mathrm{~d}$ in medium containing IL-2, then left untreated (Resting) or re-stimulated for $1 \mathrm{~h}$ with PMA and ionomycin (Restim) (left margin). Below, enlargement of three areas of enrichment for NFAT-1 binding detected in re-stimulated cells by the HOMER suite of tools for motif discovery. Top, positions of the pre-miR-31 hairpin (blue arrow, location and direction of transcription), the CpG island, and the predicted transcription start site (TSS) of Mir31. Data are representative of two experiments (error bars (a,b), s.d.). 

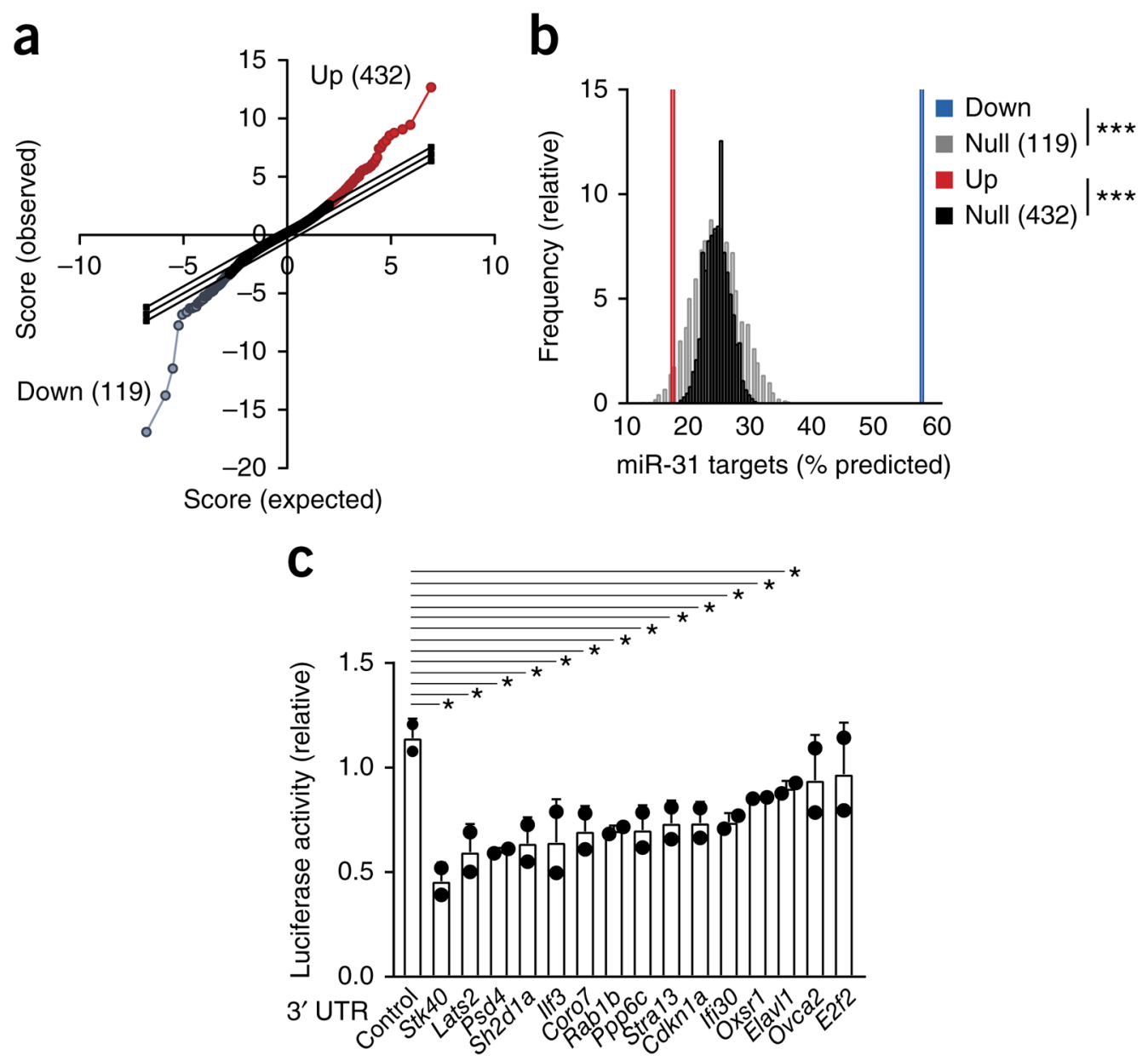

Figure 3.

Microarray profiling reveals targets of miR-31 in primary CD8 ${ }^{+} \mathrm{T}$ cells. (a) Microarray analysis of gene expression in $\mathrm{CD}^{+} \mathrm{T}$ cells transduced with lenti-miR31 relative to that of cells transduced with lenti-eGFP (T scores): diagonal lines indicate expected null distribution (middle line) and significance cutoffs (top and bottom lines); colors indicate probes significantly downregulated (blue) or upregulated (red), as determined by the SAM (significance analysis of microarrays) technique; in parentheses, number of upregulated probes (Up; top right) or downregulated probes (Down; bottom left). (b) Frequency of predicted miR-31 target genes among the 119 downregulated probes and 432 upregulated probes in a (key), and matching null distributions generated from probes not expressed differentially (Null). $* * * P<0.001$, up- or downregulated probe versus the corresponding null distribution (one-sample $t$-test). (c) Luciferin bioluminescence assay of cells transduced with a luciferase reporter gene containing no $3^{\prime}$ UTR (Control) or the $3^{\prime}$ UTR of predicted miR-31 target genes (horizontal axis), in the presence of exogenous miR-31; results are presented relative to those obtained in the absence of exogenous miR-31. Each symbol represents an individual experiment. $* P=0.008,0.02,0.007,0.02,0.04,0.03,0.01,0.03$. $0.03,0.03,0.01,0.02$ or 0.04 (left to right), versus control reporter (unpaired one-tailed Student's $t$-test). Data are representative of one experiment $(\mathbf{a}, \mathbf{b})$ or three experiments $(\mathbf{c}$; mean + s.d.). 


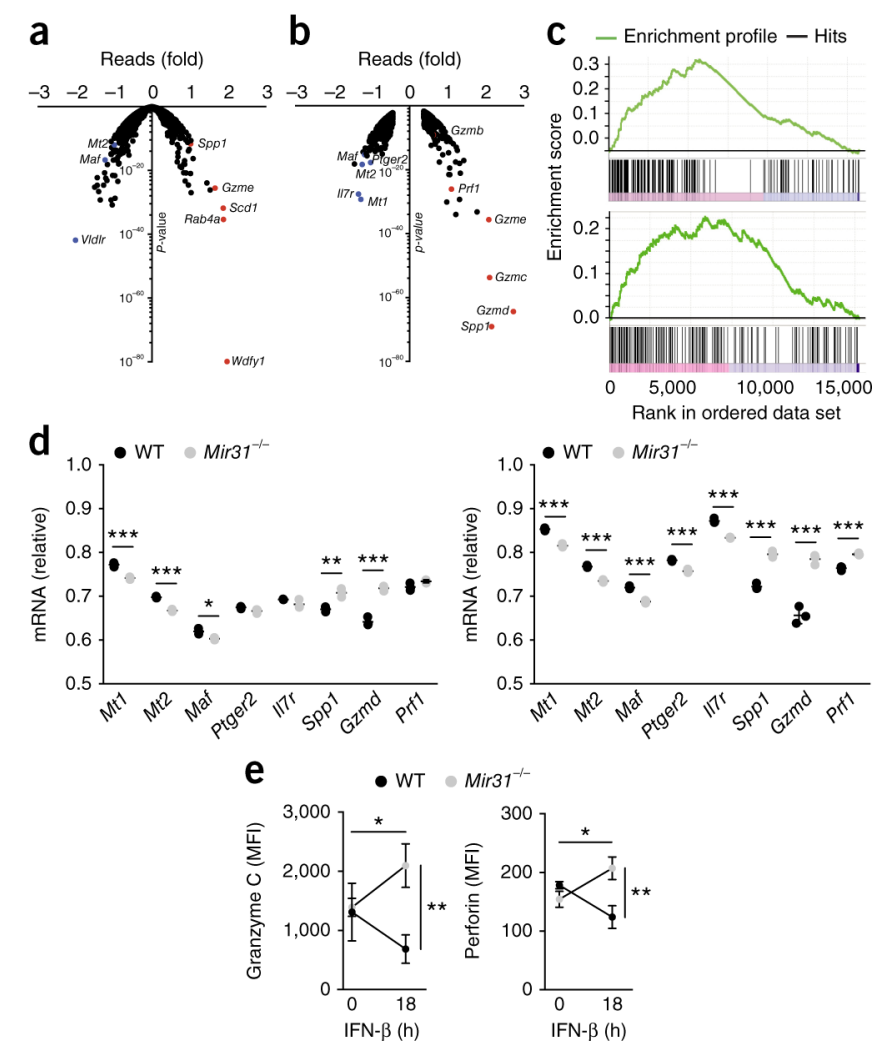

Figure 4.

miR-31 limits $\mathrm{CD} 8^{+} \mathrm{T}$ cell effector programs and enhances exhaustion following stimulation with IFN- $\beta$. (a,b) RNA-seq analysis of wild-type and Mir31-1- $\mathrm{CD}^{+} \mathrm{T}$ cells activated with beads coated with anti-CD3 plus anti-CD28 and then cultured for $7 \mathrm{~d}$ in IL-2, then left unstimulated (a) or stimulated for $18 \mathrm{~h}$ with IFN- $\beta$ (b); results for Mir $31^{-1-}$ cells are presented relative to those of wild-type cells (red and blue dots indicate relevant genes or genes with the most differential expression (labels adjacent)). (c) Gene-set-enrichment analysis of cells at $0 \mathrm{~h}$ (top) and $18 \mathrm{~h}$ (bottom) after stimulation with IFN- $\beta$, highlighting the 'LCMV Armstrong versus clone 13' program (top; normalized enrichment score $=5.728$; FDR $q$ value, <0.001) and 'Effector versus Exhausted T cell' program (bottom; normalized enrichment score $=3.509$; FDR $q$ value, $<0.001$ ). (d) qPCR analysis of genes encoding products associated with $\mathrm{T}$ cell dysfunction and effector-memory programs (horizontal axes), assessed in wild-type (WT) and Mir31-l- T cells (key) at $0 \mathrm{~h}$ (left) and $18 \mathrm{~h}$ (right) after stimulation with IFN- $\beta$; results are presented relative to those of the control gene Gapdh. (e) Flow-cytometry analysis of granzyme C (left) and perforin (right) in wild-type and Mir31-1- cells T cells (key) at $0 \mathrm{~h}$ and $18 \mathrm{~h}$ after stimulation with IFN- $\beta$ (horizontal axes); results are presented as mean fluorescence intensity (MFI). $* P<0.05, * * P<0.01$ and *** $P<0.001$ (unpaired two-tailed Student's $t$-test). Data are from one experiment $(\mathbf{a}-\mathbf{c})$ or two independent experiments (d,e) with $n=3$ cultures from three mice (mean \pm s.d. in d,e). 

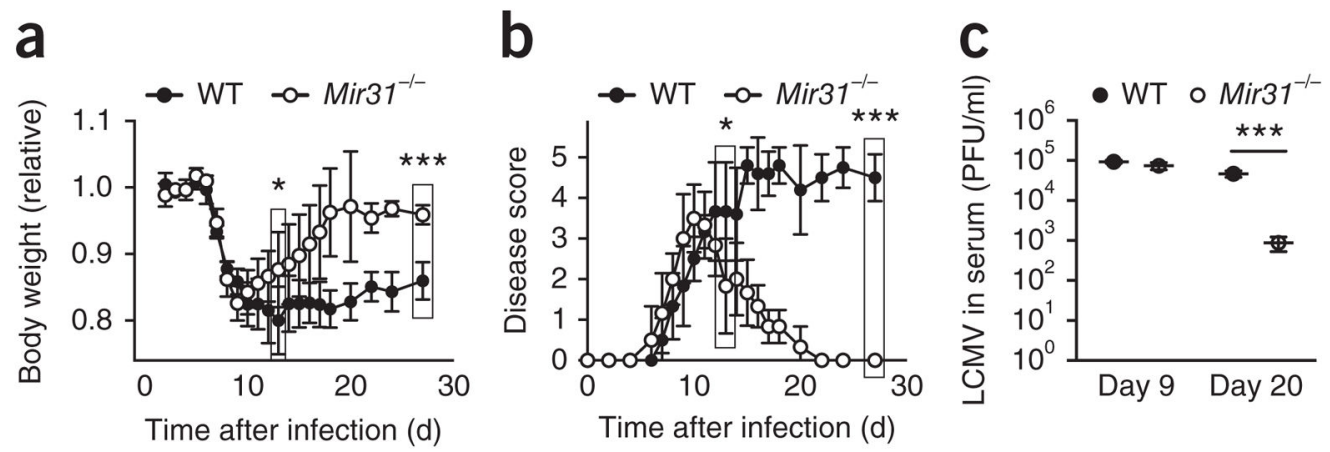

Figure 5.

Mir31 $1^{-1-}$ mice undergo a faster recovery and show better viral control in a chronic-LMCVinfection model. (a) Body weight of wild-type mice $(n=4)$ and $\operatorname{Mir} 31^{-1-}$ mice $(n=6)$ (key) infected intravenously with LCMV clone $13\left(1 \times 10^{6}\right.$ plaque-forming units), assessed daily before (day 0) and after infection (time, horizontal axis); results are presented relative to original body weight (day 0 ). ${ }^{*} P=0.02$ (day 13) and $* * * P=0.003$ (day 27) (unpaired twotailed Student's $t$-test). (b) Disease scores of wild-type mice $(n=4)$ and Mir31-1- mice $(n=$ 6) as in a. $* P=0.024$ (day 13) and $* * * P=4.5 \times 10^{-8}$ (day 27) (unpaired two-tailed Student's $t$-test). (c) Viral load in the serum of mice as in a ( $n=3$ per group), assessed by plaque assay at days 9 and 20 after infection (horizontal axis) and presented as plaqueforming units (PFU) per $\mathrm{ml}$ serum. Each symbol represents an individual mouse; small horizontal lines indicate the mean ( \pm s.d.). $* * * P=0.0008$ (unpaired two-tailed Student's $t$ test). Data are representative of two experiments (mean \pm s.d. in $\mathbf{a}, \mathbf{b}$ ). 

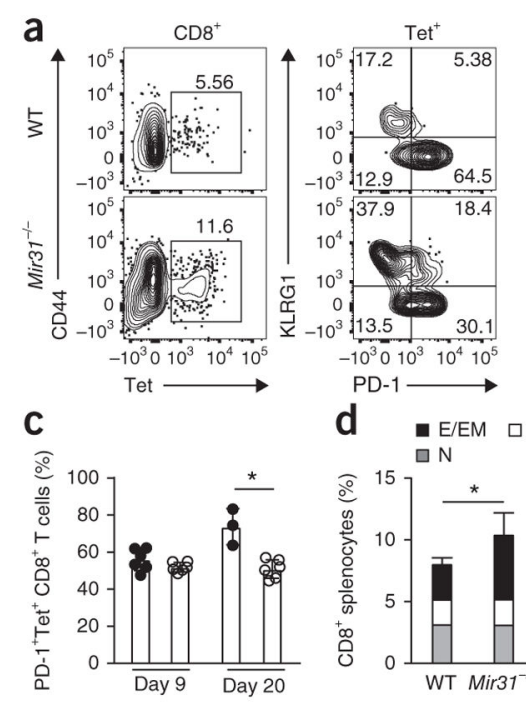

b $=\mathrm{KLRG}^{+}$

$\square \mathrm{KLRG}^{-}$
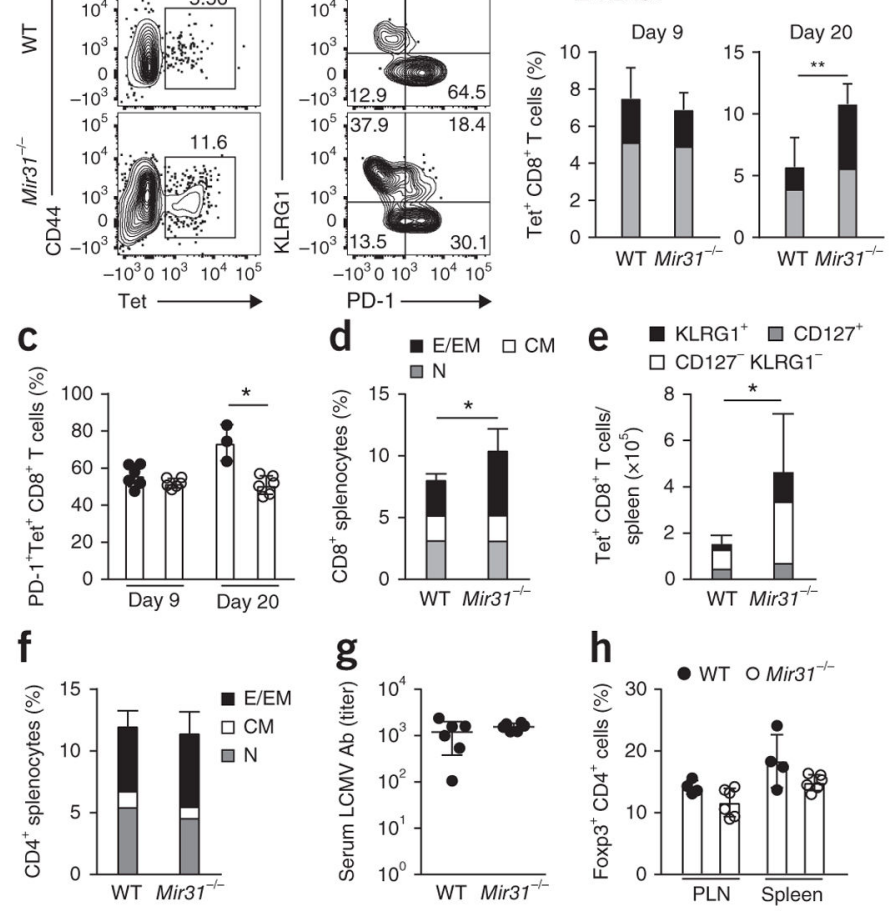

\section{Figure 6.}

Enhanced LCMV-specific CD8 ${ }^{+} \mathrm{T}$ cell responses in miR-31 deficient mice. (a) Flow cytometry of $\mathrm{CD} 8^{+} \mathrm{T}$ cells from the blood of wild-type and Mir $31^{-1-}$ mice (left margin) on day 20 after infection with LCMV clone 13 (left), and surface expression of KLRG1 and PD-1 on Tet $^{+} \mathrm{CD}^{+}{ }^{+}$cells gated as at left (right). Numbers adjacent to outlined areas (left) indicate percent $\mathrm{CD} 44^{+} \mathrm{Tet}^{+}$cells; numbers in quadrants (right) indicate percent cells in each. (b) Frequency of KLRG1 $1^{+}$and KLRG1- cells (key) among $\mathrm{Tet}^{+} \mathrm{CD}^{+} \mathrm{T}$ cells in the blood of wild-type mice $(n=4)$ and $\operatorname{Mir} 31^{-1-}$ mice $(n=6)$ (horizontal axis) on days 9 and 20 (above plots) after infection as in a. ${ }^{* *} P=0.002$ (unpaired two-tailed Student's $t$-test). (c) Frequency of PD- $1^{+} \mathrm{Tet}^{+} \mathrm{CD} 8^{+} \mathrm{T}$ cells in wild-type mice $(n=3)$ and $\mathrm{Mir} 31^{-1-}$ mice $(n=6)$ (key) on days 9 and 20 (horizontal axis) after infection as in $\mathbf{a} . * P=0.02$ (unpaired twotailed Student's $t$-test). (d) Flow cytometry of effector and effector-memory $\left(\mathrm{CD} 44^{+} \mathrm{CD} 2 \mathrm{~L}^{-}\right) \mathrm{CD}^{+} \mathrm{T}$ cells $(\mathrm{E}-\mathrm{EM})$, central memory $\left(\mathrm{CD} 44^{+} \mathrm{CD}^{-} \mathrm{L}^{+}\right) \mathrm{CD}^{+} \mathrm{T}$ cells $(\mathrm{CM})$ and naive $\left(\mathrm{CD} 44^{-} \mathrm{CD}^{-} \mathrm{L}^{+}\right) \mathrm{CD} 8^{+} \mathrm{T}$ cells $(\mathrm{N})(\mathrm{key})$ in the spleen of wild-type mice $(n$ $=4)$ and $M i r 31^{-1-}$ mice $(n=6)$ (horizontal axis) on day 30 after infection as in a. $* P=0.03$ (unpaired two-tailed Student's $t$-test). (e) Quantification of total KLRG1 ${ }^{+}, \mathrm{CD} 127^{-} \mathrm{KLRG1}{ }^{-}$ and $\mathrm{CD} 127^{+}$cells (key) among $\mathrm{Tet}^{+} \mathrm{CD} 8^{+} \mathrm{T}$ cells in the spleen of mice as in $\mathbf{d} . * P=0.04$ (unpaired two-tailed Student's $t$-test). (f) Flow cytometry of $\mathrm{CD} 4^{+} \mathrm{T}$ cell populations, gated as in $\mathbf{d}$ (key), in the spleen mice as in $\mathbf{d}$. (g) ELISA of LCMV-specific antibodies (LCMV $\mathrm{Ab}$ ) in the serum of wild-type and Mir $31^{-/-}$mice (horizontal axis) on day 20 after infection with LCMV clone 13. (h) Frequency of Foxp $3^{+} \mathrm{CD} 4^{+} \mathrm{T}$ cells in peripheral lymph nodes (PLN) and spleen (horizontal axis) of wild-type and Mir $31^{-1-}$ mice (key) on day 30 after infection with LCMV clone 13. Each symbol (c,g,h) represents an individual mouse; small 
horizontal lines $(\mathbf{g})$ indicate the mean $( \pm$ s.d.). Data are representative of two experiments (error bars (b-f,h), s.d.). 

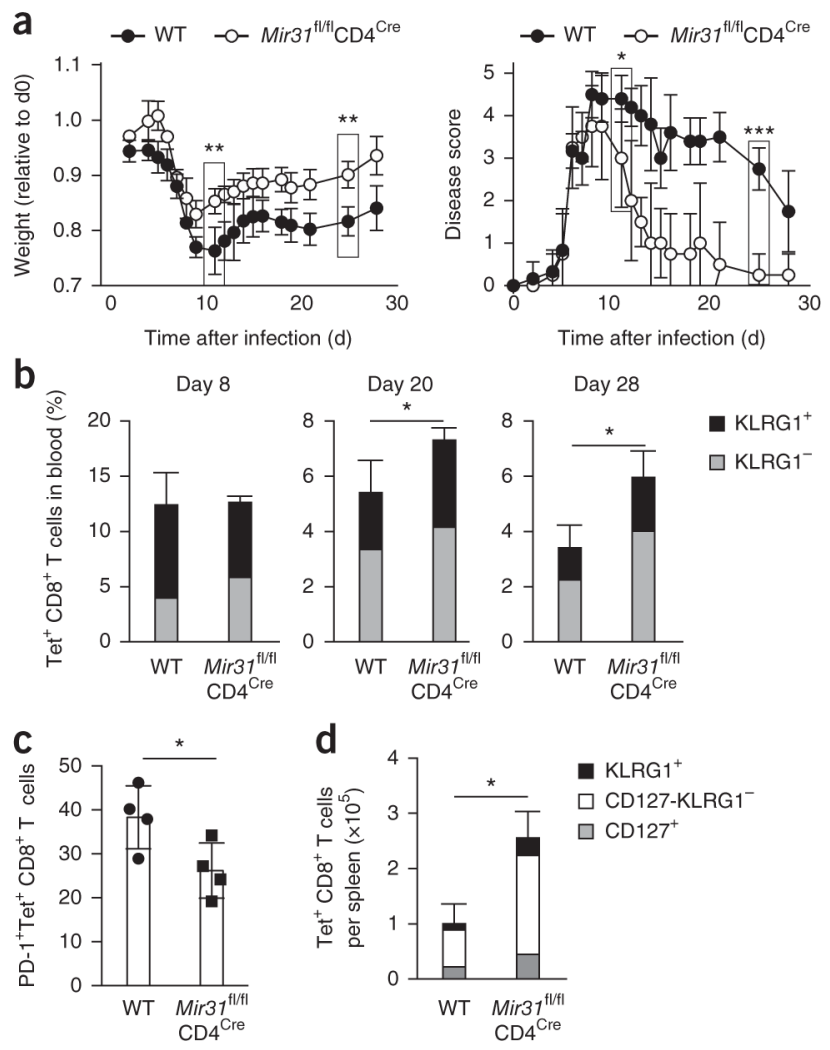

Figure 7.

$\mathrm{T}$ cell-intrinsic effect of miR-31 on anti-viral CD8 $8^{+} \mathrm{T}$ cell responses during chronic infection with LCMV. (a) Body weight (left) and disease scores (right) of wild-type and Mir $3 f^{\mathrm{fl} / \mathrm{fl}} \mathrm{Cd} 4^{\mathrm{Cre}}$ mice ( $n=4$ per group) infected intravenously with LCMV clone $13(1 \times$ $10^{6}$ plaque-forming units), assessed daily before (day 0 ) and following infection; weight is presented relative to starting body weight (day 0 ). $* * P=0.003$ (day 12) and $* * P=0.001$ (day 25), body weight; $* P=0.01$ (day 12) and $* * * P=0.0004$ (day 25), disease score (unpaired two-tailed Student's $t$-test). (b) Frequency of KLRG1 ${ }^{+}$and KLRG1 ${ }^{-}$cells (key) among $\mathrm{Tet}^{+} \mathrm{CD} 8^{+} \mathrm{T}$ cells in the blood of mice as in $\mathbf{a}$ ( $n=4$ per group), assessed by flow cytometry at days 8,20 and 28 after infection. $* P=0.02$ (day 20) and $* P=0.03$ (day 28) (unpaired two-tailed Student's $t$-test). (c) Frequency of PD- $1^{+} \mathrm{Tet}^{+} \mathrm{CD} 8^{+} \mathrm{T}$ cells in the blood of mice as in $\mathbf{a}$ ( $n=4$ per group), assessed by flow cytometry at day 20 after infection treated. $* P=0.04$ (unpaired two-tailed Student's $t$-test). (d) Quantification of KLRG1 ${ }^{+}$, CD127- $\mathrm{KLRG1}^{-}$and $\mathrm{CD} 127^{+}$cells (key) among $\mathrm{Tet}^{+} \mathrm{CD}^{+} \mathrm{T}$ cells in the spleen of mice treated as in a ( $n=4$ per group), assessed by flow cytometry. Each symbol (c) represents an individual mouse. $* P=0.002$ (unpaired two-tailed Student's $t$-test). Data are representative of one experiment (error bars, s.d.). 

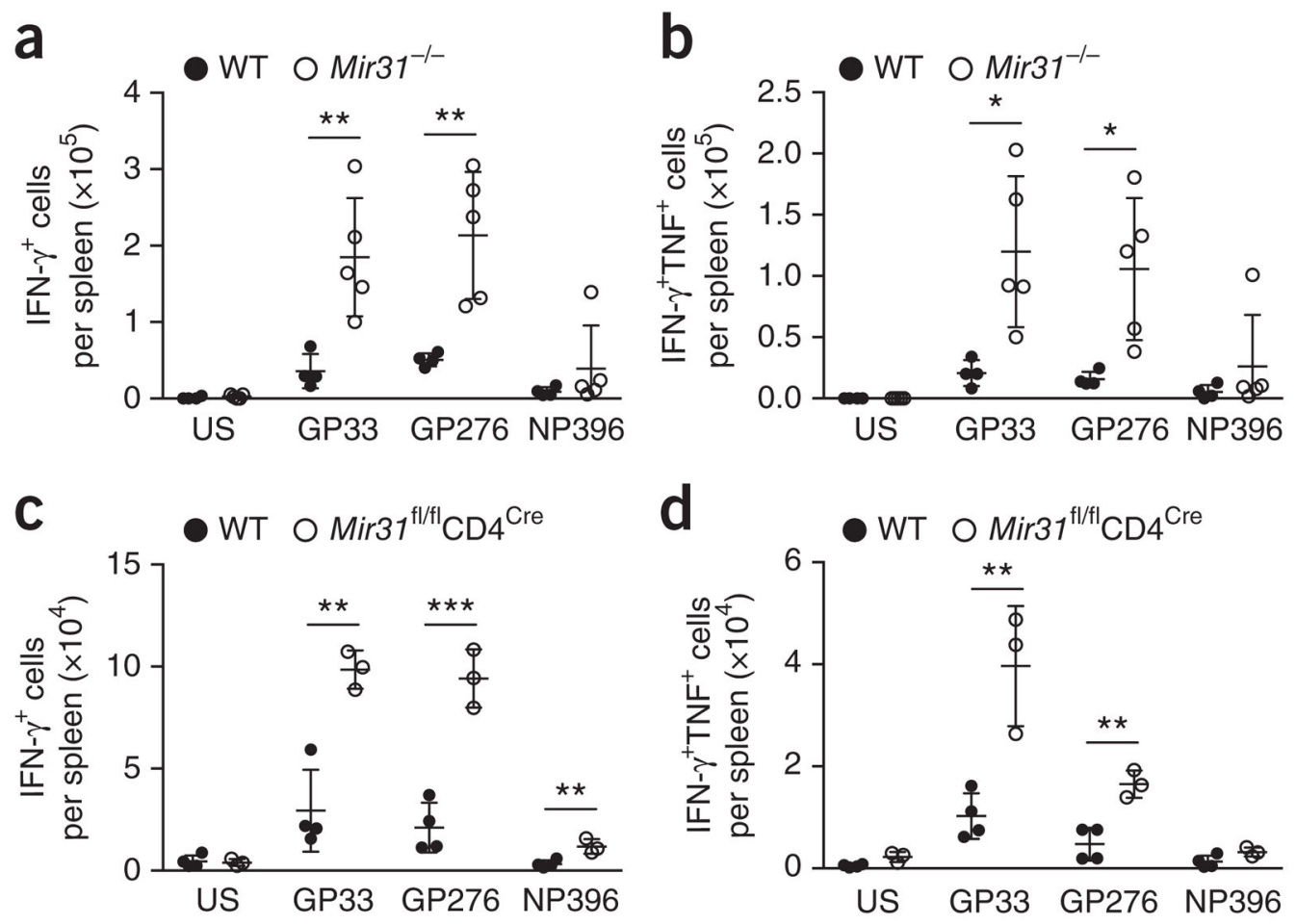

Figure 8.

Enhanced production of cytokines by LCMV-specific CD8 ${ }^{+} \mathrm{T}$ cells in the absence of miR-31. Quantification of IFN- $\gamma^{+} \mathrm{CD}^{+} \mathrm{T}$ cells $(\mathbf{a}, \mathbf{c})$ or IFN- $\gamma^{+} \mathrm{TNF}^{+} \mathrm{CD} 8^{+} \mathrm{T}$ cells $(\mathbf{b}, \mathbf{d})$ among splenocytes obtained from wild-type mice $(n=4)$ or $\operatorname{Mir31^{-1}}$ mice $(n=6)$ at day 30 after infection with LCMV clone 13 (a,b) or obtained from wild-type and Mir3 $1^{\mathrm{fl} / \mathrm{fl}} \mathrm{Cd} \mathrm{C}^{\mathrm{Cre}}$ mice ( $n=4$ per group) at day 28 after infection with LCMV clone $13(\mathbf{c}, \mathbf{d})$, then left unstimulated (US) or pulsed for $5 \mathrm{~h}$ with GP33, GP276 or NP396 peptide $(10 \mu \mathrm{g} / \mathrm{ml})$ (horizontal axes) in the presence of brefeldin A and assessed by intracellular staining; results are presented as total positive cells per spleen. Each symbol represents an individual mouse; small horizontal lines the mean ( \pm s.d.). $* * P=0.008$ (GP33) and $* * P=0.006$ (GP276) (a); $* P=0.005$ (GP33) or $* P=0.009$ (GP276) (b); $* * P=0.002(\mathrm{GP} 33), * * * P=0.0007$ (GP276) or $* * P=0.008(\mathrm{NP} 396)(\mathbf{c})$; and $* * P=0.005$ (GP33) or $* * P=0.003$ (GP276) (d) (unpaired two-tailed Student's $t$-test). Data are representative of two experiments $(\mathbf{a}, \mathbf{b})$ or one experiment (c,d). 